\title{
A Comprehensive Review on Function and Application of Plant Peroxidases
}

\author{
Veda P Pandey, Manika Awasthi, Swati Singh, Sameeksha Tiwari and Upendra N Dwivedi*
}

Bioinformatics Infrastructure Facility, Center of Excellence in Bioinformatics, Department of Biochemistry, University of Lucknow, Uttar Pradesh, India

\begin{abstract}
Peroxidases, one of the key antioxidant enzymes, are widely distributed in nature and catalyze oxidation of various electron donor substrates concomitant with the decomposition of $\mathrm{H}_{2} \mathrm{O}_{2}$. The non-animal plant peroxidases (class III peroxidase) are involved in various essential physiological processes of plant growth and development throughout their life cycle. In view of the capability of peroxidases to catalyze the redox reaction for a wide range of substrates, they are considered as one of the important enzyme from the point of view of their various medicinal, biochemical, immunological, biotechnological and industrial applications. They have been successfully used for biopulping and biobleaching in the paper and textile industries. Peroxidases have also been used in organic synthesis, bioremediation, as well as various analytical applications in diagnostic kits, ELISA. Peroxidase based biosensors find application in analytical systems for determination of hydrogen peroxide, glucose, alcohols, glutamate, and choline etc. Thus, in view of array of physiological functions as well as industrial applications, the peroxidases have conquered a dominant position in research groups and become one of the most extensively studied enzymes. In this direction, the present review embodies the classification, mechanism of action, major physiological functions as well as industrial applications of plant peroxidases.
\end{abstract}

Keywords: Heme peroxidase; Analytical applications; Biosensor development; Class III peroxidase; Dye decolorization

\section{Introduction}

Development of environmentally sustainable processes is a challengeable task for the current bioeconomy. In this direction, the use of biocatalysts, enzymes, in various processes is considered as an ecofriendly approach. The stability, activity and specificity of enzymes are the fundamental parameters that are required to develop enzymes for their optimal applications in various industrial processes. Therefore, identification of newer sources for such novel enzymes with desired properties is important. Furthermore, modern approaches such as insilico molecular modeling concomitant with site directed mutagenesis to develop such novel enzymes with improved attributes are also in great demand. The present thesis is an effort in this direction.

Peroxidases (EC.1.11.1.x) are hydrogen peroxide $\left(\mathrm{H}_{2} \mathrm{O}_{2}\right)$ decomposing enzymes concomitant with the oxidation of wide range of phenolic as well as non- phenolic substrates $(\mathrm{RH})$

$$
2 \mathrm{RH}+\mathrm{H}_{2} \mathrm{O}_{2} \rightarrow 2 \mathrm{R}^{\circ}+2 \mathrm{H}_{2} \mathrm{O}
$$

They are ubiquitous in nature being found in bacteria, fungi, algae, plants and animals. The plant peroxidases, belonging to Class III peroxidase, are implicated in various vital processes of plant growth and development throughout the plant life cycle including cell wall metabolism, lignification, suberization, reactive oxygen species (ROS) metabolism, auxin metabolism, fruit growth and ripening, defense against pathogens etc. Due to versatility in reaction catalyzed by peroxidases, and their ubiquitous nature, they have immense potential to be an industrial enzyme with application in various medicinal, immunological, biotechnological and industrial sectors. The peroxidases find applications in bioremediation, textile synthetic dye decolorization, polymer synthesis, paper and pulp industry, in development of biosensor, diagnosis kits etc. In view of various applications, the identification of newer sources of novel peroxidase offering resistance towards temperature, $\mathrm{pH}$, salts, heavy metals, organic solvents etc. is highly desirable. Thus, the present review is an attempt to summarize various physiological functions as well as the industrial applications of plant peroxidases.

\section{Classification of peroxidases}

On the basis of presence or absence of heme, the peroxidases have been classified into heme and non-heme peroxidases [1]. According to PeroxiBase database, $>80 \%$ of known peroxidase genes are reported to code for heme-containing peroxidases. On the other hand, the nonheme peroxidases such as thiol peroxidase, alkylhydroperoxidase, NADH peroxidase constitute only a small proportion. Since majority of the peroxidase sequences are reported to be heme peroxidases, thus they are described in detail.

Heme peroxidases have further been assigned to two superfamilies, namely peroxidase-cyclooxygenase superfamily (PCOXS) and the peroxidase-catalase superfamily (PCATS) [2,3]. Description of these peroxidase superfamilies are presented as follows. A schematic classification of peroxidases is presented in Figure 1.

The Peroxidase-Cyclooxygenase Superfamily (PCOXS): The peroxidases of PCOXS superfamily exclusively contain animal peroxidases which have been suggested to be involved in the innate immunity, defense responses etc. [4,5]. The myeloperoxidase (MPO), eosinophil peroxidase (EPO), lactoperoxidase (LPO), thyroid peroxidase (TPO) are belonging to this family. In this superfamily, the prosthetic heme group is covalently linked with the apoprotein.

The Peroxidase-Catalase Superfamily (PCATS): The PCATS is the most intensively studied superfamily of non-animal heme peroxidases.

*Corresponding author: Upendra N Dwivedi, Department of Biochemistry, University of Lucknow, Lucknow 226007, Uttar Pradesh, India, Tel: +91-522-2740132; E-mail: upendradwivedi@hotmail.com

Received: November 03, 2016; Accepted: January 21, 2017; Published January 24, 2017

Citation: Pandey VP, Awasthi M, Singh S, Tiwari S, Dwivedi UN (2017) A Comprehensive Review on Function and Application of Plant Peroxidases. Biochem Anal Biochem 6: 308. doi: 10.4172/2161-1009.1000308

Copyright: (c) 2017 Pandey VP, et al. This is an open-access article distributed under the terms of the Creative Commons Attribution License, which permits unrestricted use, distribution, and reproduction in any medium, provided the original author and source are credited. 


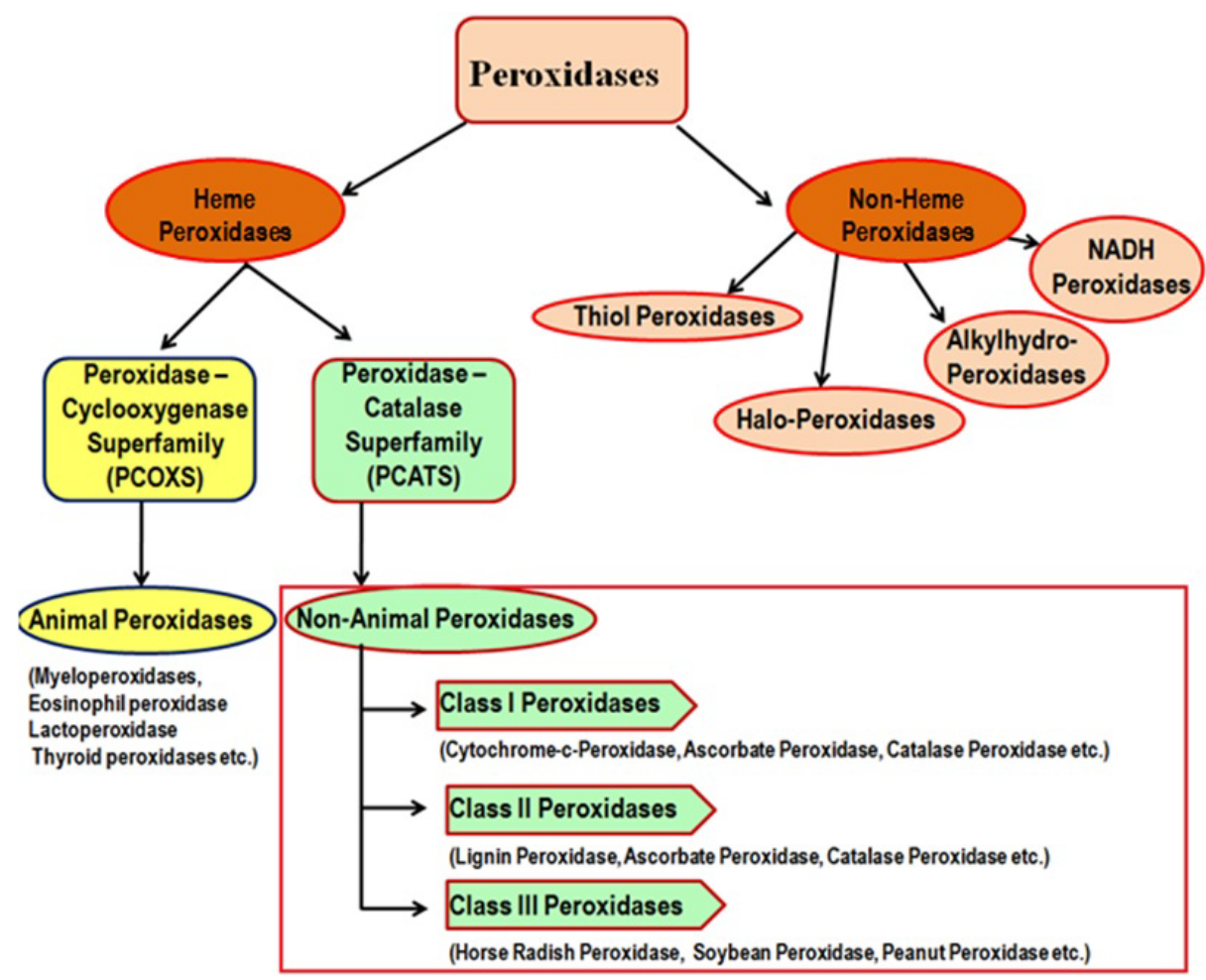

Figure 1: Schematic representation of classification of peroxidases.

Initially, the superfamily was named as the plant, fungal and bacterial heme peroxidase superfamily depending upon the sources of the peroxidases. Later on, due to emergence of new cnidarians peroxidase, the name of this superfamily was changed as peroxidase-catalase superfamily.

The non-animal peroxidases have further been sub-divided into three classes namely, class I, II and III peroxidases as described in following sections.

(a) Class I Peroxidases: The class I peroxidases include both prokaryotic and eukaryotic peroxidases belonging to non-animal sources. Currently, 1839 sequences of this class are reported in PeroxiBase database. They exhibited major role in oxidative stress i.e., detoxification of ROS $\left(\mathrm{H}_{2} \mathrm{O}_{2}\right)$ [6-8]. They include cytochrome c peroxidase (CCP; EC 1.11.1.5), ascorbate peroxidase (APX; EC 1.11.1.11) and catalase peroxidase (CP; EC 1.11.1.6). The cytochrome $c$ peroxidase (CCP), uses reducing equivalents from cytochrome $c$ and reduces hydrogen peroxide to water. Ascorbate peroxidases (APx) are involved in hydrogen peroxide detoxification using ascorbate as reducing equivalents as well as in photo-protection of the chloroplasts and cytosol in higher plants $[9,10]$. The catalase-peroxidases (CPs), predominantly reported in bacteria, are bi-functional antioxidant enzymes that exhibit both catalase and peroxidase enzyme activity. Due to their unique catalytic capacity to dismutate hydrogen peroxide and ability to evolve molecular oxygen $\left(\mathrm{O}_{2}\right)$ by oxidation of $\mathrm{H}_{2} \mathrm{O}_{2}$, they prevent bacteria from oxidative stress [11]. Evolutionary they are closely related to ascorbate peroxidases and cytochrome c-peroxidases $[12,13]$. At the structural level, the class I peroxidases lack disulphide bridges, calcium and an endoplasmic reticulum signal sequence.

(b) Class II Peroxidases: The class II peroxidases, exclusively containing fungal peroxidases, have major role in lignin biodegradation
[14]. In the PeroxiBase database, 609 sequences of class II peroxidases are reported till date. White-rot fungal lignin peroxidases (LiPs; EC 1.11.1.14) are secretary in nature and catalyze depolymerization of lignin as well as possess immense potentials for waste disposal of a number of phenolic as well as non-phenolic compounds. Manganese peroxidases (MnP; EC 1.11.1.13), are also secreted by lignin-degrading white-rot fungi. They catalyze the peroxide-dependent oxidation of $\mathrm{Mn}$ (II) to Mn (III) and the Mn (III) is released from the enzyme as oxalate$\mathrm{Mn}$ (III) complex that serve as diffusible redox mediator having ability to oxidize lignin. Versatile peroxidases (VP; EC 1.11.1.16) exhibited a hybrid molecular architecture between LiPs and MnPs [15]. They are not only specific for $\mathrm{Mn}$ (II) as in $3 \mathrm{MnPs}$, but also catalyze the oxidation of phenolic and non-phenolic substrates like LiPs, in the absence of manganese [16]. In contrary to class I peroxidases, the class II peroxidases have $\mathrm{N}$-terminal signal peptides, four conserved disulphide bridges (differently located to those of class III) and calcium in their structure.

(c) Class III Peroxidases: The class III peroxidases are widely distributed in plant kingdom [17,18]. In the PeroxiBase database [1], 5692 sequences of class III peroxidases ( $70 \%$ of total non-animal heme peroxidases) are reported till date. They include horseradish peroxidases (HRP), peanut peroxidase (PNP), soybean peroxidase (SBP), etc. and they are reported to play crucial roles in the plant life cycle [19]. Thus, they are involved in wide range of physiological processes such as cell wall metabolism [20], lignification [21], suberization [22], auxins metabolism [23], wound healing [24], reactive oxygen species (ROS) and reactive nitrogen species (RNS) metabolism $[25,26]$, fruit growth and ripening [27] defense against pathogens [28] etc. These peroxidases exist as multigene family as evident by 73 and 138 peroxidase genes in the genomic sequences of Arabidopsis (Arabidopsis Genome Initiative, 2000) and rice (International Rice Genome Sequencing Project, 2005), 


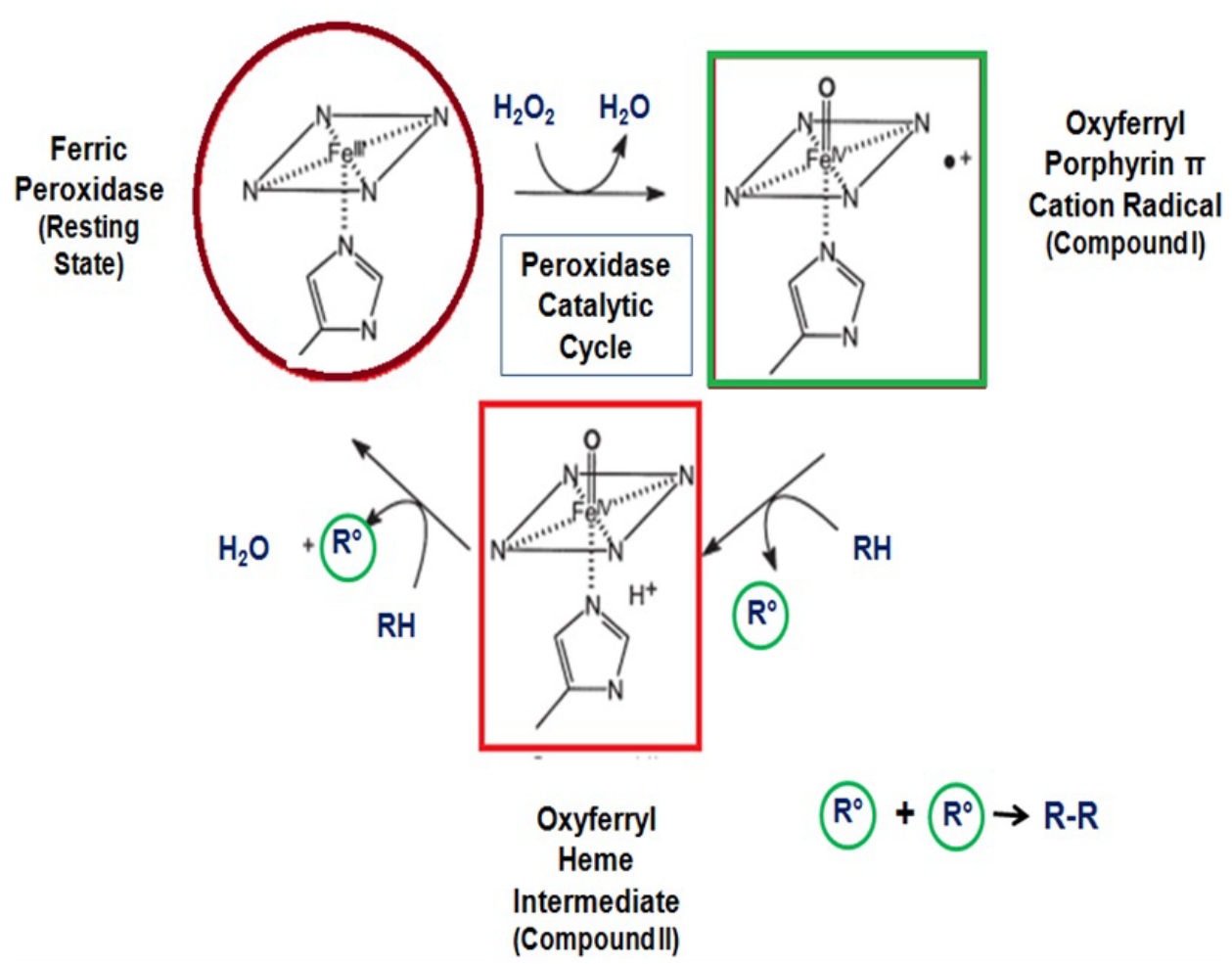

Figure 2: Catalytic cycle of heme peroxidases showing catalytic events (oxidation-reduction) occur at heme (Fe ${ }^{+}$porphyrin IX) center of the enzyme. At the end of the reaction, $\mathrm{H}_{2} \mathrm{O}_{2}$ is degraded to $\mathrm{H}_{2} \mathrm{O}$ and reducing equivalent $(\mathrm{RH})$ is polymerized.

respectively $[17,29,30]$. Similar to class II peroxidases, in the structural fold, the class III peroxidases also contain N-terminal signal peptides, four conserved disulphide bridges and calcium. In the present review, the class III plant peroxidases are detailed below.

\section{Evolutionary relationship between heme peroxidases}

The heme peroxidases of non-animal origin show low amino acid sequence identity (less than 20\%) but, share similar helical folds independent to the presence (in plant and fungal peroxidases) and absence (in bacterial peroxidases) of disulfide bridges and structural calcium ions. Recently [31] have also studied the comparative account of non-animal heme peroxidases and reported that the peroxidases are clustered into three major classes. In addition, [6] have suggested that the class I peroxidases are the origin point for the other two classes of peroxidases.

\section{Mechanism of action}

Peroxidases share a common catalytic mechanism for the degradation of hydrogen peroxide [32]. The peroxidase reaction is a two-electron oxidation-reduction with three distinct steps [33] :

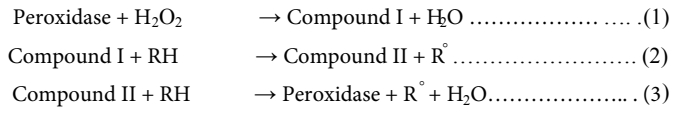

Where, $\mathrm{RH}$ is a peroxidase substrate and $\mathrm{R}^{\circ}$ is a free-radical product derived from it.

The catalytic cycle of heme peroxidases specific to plants begins with the coordination of peroxide to the ferric heme (Figure 2). The coordinated peroxide undergoes rapid heterolytic cleavage, producing a molecule of water and the semi-stable intermediate referred to as compound I (green in color, and also referred as oxyferryl porphyrin $\pi$ cation radical). The reaction involves transfer of a proton from peroxide $\mathrm{O}_{1}$ to $\mathrm{O}_{2}$, followed by breaking of $\mathrm{O}-\mathrm{O}$ bond. Departure of $\mathrm{O}_{2}$ as water molecule leaves $\mathrm{O}_{1}$ that is already coordinated to the heme with only six electrons. It completes its octate by abstracting the two most readily available electrons from the enzyme. One electron is removed from the iron, creating an oxy-ferryl $(\mathrm{Fe}=\mathrm{O})$ center. Generally, in case of most of the peroxidases, the second electron is removed from the porphyrin ring, creating a porphyrin pi-cation radical.

This porphyrin radical accepts one electron from an electron donor substrate, yielding a substrate free radical and compound II (red in color and referred as oxyferryl heme intermediate). In the next one-electron reduction step from a second molecule of the substrate reduces compound II to the resting ferric peroxidase [34,35].

Another intermediate namely the compound III, in which the iron is in the ferrous state, is usually formed when there is a large excess of $\mathrm{H}_{2} \mathrm{O}_{2}$. It is likely that this intermediate is largely formed by combination of superoxide, generated by the oxidation of $\mathrm{H}_{2} \mathrm{O}_{2}$, with the ferric enzyme, although superoxide could also be generated by electron transfer from oxidized substrates to molecular oxygen. Compound III is not a catalytically active intermediate.

\section{Physiological roles of plant peroxidases}

Class III plant peroxidases have been reported to play diverse functions in the plant life cycle such as in cell wall metabolism, lignification, suberization, ROS metabolism, wound healing, fruit growth and ripening, seed germination etc. [36]. A schematic representation of diverse functions of class III peroxidases is presented 


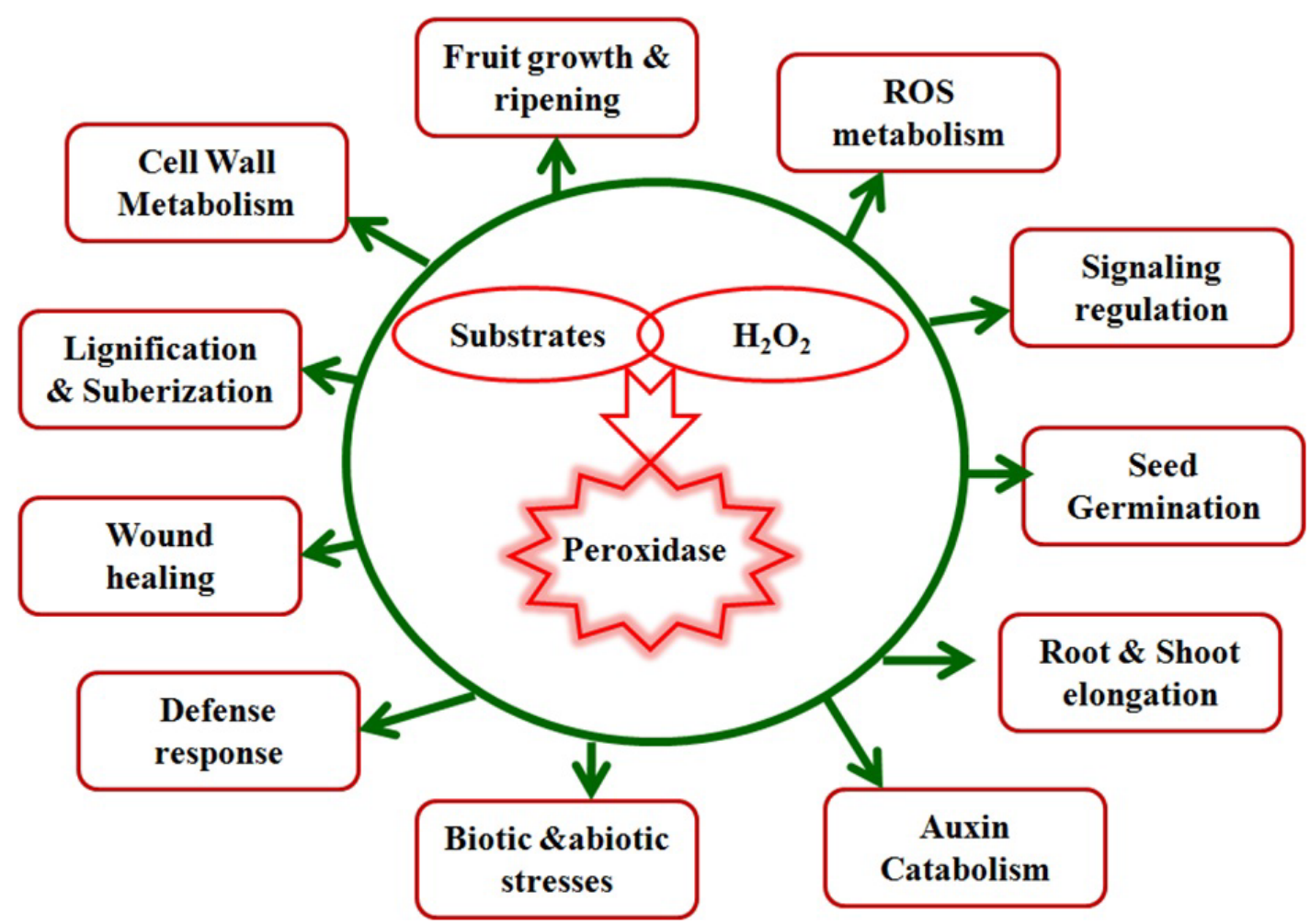

Figure 3: A schematic representation of various roles of plant peroxidases.

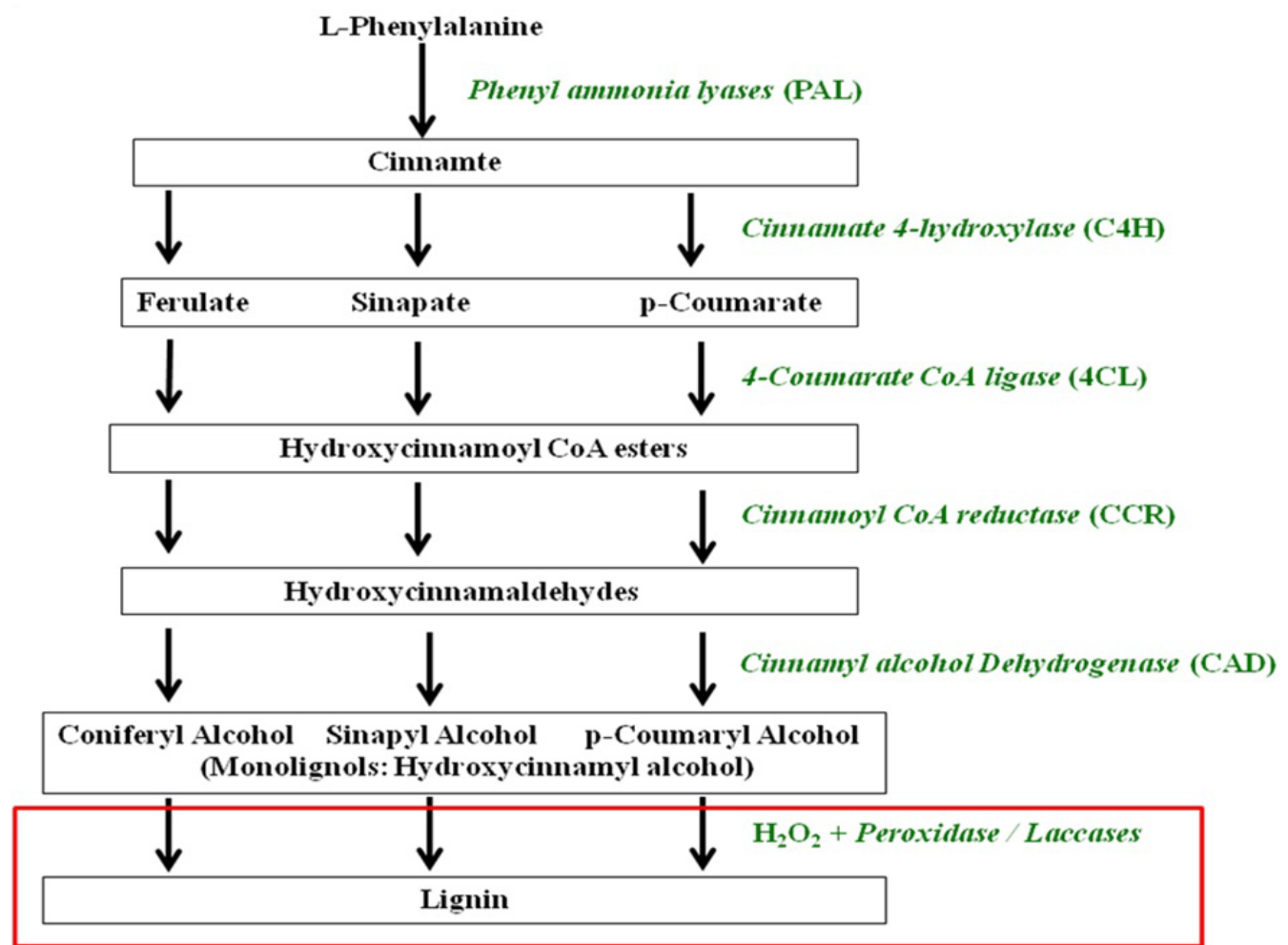

Figure 4: Generalized lignin biosynthesis pathway indicating the role of peroxidases. 
in Figure 3. Some major roles of peroxidases are described in following sections:

\section{Lignification and suberization}

Lignification occurs during normal growth and defense responses in plants and is one of the classical functions attributed to Class III peroxidases [37]. Lignin, a phenolic heteropolymer, present in the cell wall of plants and provides rigidity, strength, and resistance to chemical, physical as well as biological attacks. Lignin which contributes about $25 \%$ of the plant biomass is considered as one of the greatest obstacle towards the optimal utilization of the plant biomass for various purposes such as paper manufacturing, production of highly palatable forage and bagasse utilization.

Chemically, lignin is made up of mainly three types of monolignols, namely p-coumaryl alcohol, sinapyl alcohol and coniferyl alcohol. These monolignols are synthesized via phenyl propanoid (PP) pathway which starts with deamination of phenylalanine, followed by successive hydroxylations, methylations, thiol ester formation and two reduction reactions leading to the formation of the three major kinds of monolignols. These monolignols are transported to cell wall in the form of glycosides and there glucosidase enzyme release the monolignols.

The polymerization of the monolignols, into lignin involves an oxidative mechanism with the consequent formation of phenoxy radicals, through the action of oxidative enzymes, such as peroxidases. The schematic representation of lignin biosynthesis pathway along with the role of peroxidase is represented in Figure 4.

There are several reports suggesting higher expression of peroxidase genes in the tissues undergoing lignification [38]. Thus, Mader and Amberg- Fisher [39] have reported that the peroxidases have ability to polymerize cinnamylalcohols in the presence of hydrogen peroxide. Furthermore, based on experimental study, Andrews et al. [40] have demonstrated the link between peroxidase isoenzymes and the cross linking of cell wall components and the deposition of lignin-like phenolics in the epidermis of the tomato fruits. Christensen et al. [38] have purified and characterized five peroxidases in poplar xylem and also analyzed their correlation with lignification via oxidation of syringaldazine (a lignin monomer analogue). The recombinant papaya peroxidase was also reported to be involved in defense response and lignification via QRTPCR and activity measurement with coniferyl alcohol [41]. In addition, Ostergaard et al. [42] have reported an extracellular peroxidase from lignifying Arabidopsis thaliana cell suspension cultures. The authors have also done mutational studied and proposed a possible correlation between the enzyme and the increased levels of lignin in a mutant Arabidopsis. The evidence for a role of peroxidases in lignification has also been supported by studies on transgenic plants with altered peroxidase activity. For example, Quiroga et al. [43] showed that expression of a tomato peroxidase gene, in transgenic tobacco resulted in an increase in lignin content. Lagrimini et al. [44] have also found higher levels of lignin in transgenic tobacco with over-expressed peroxidase than the wild type plants.

Suberization has been believed to play a role in the defensive responses against the entry of pathogenic micro-organisms through a wounded part by developing physical barrier $[43,45]$. This protects tissue from water loss and pathogen invasion. Suberized tissues are found in various underground organs like roots, stolon and tuber as well as in periderm layer. They are formed as a part of wound and pathogen induced defenses of specific organs and cell types, perhaps the most familiar example being the browning of sliced potato tubers. Lignification and suberization are terminal processes of determinate and highly differentiated plant cells capable of forming secondary cell walls. The cell wall peroxidases polymerize the hydroxycinnamic acid and their derivatives by converting them into phenoxy radicals that are then deposited on the extracellular surface. The accumulation of these polymers strengthens the cell wall, thereby restricting cell expansion and pathogen invasion, and confers structural strength to the plant body, which is especially important for trees and construction of xylem vessels.

\section{Plant defense against pathogen infection}

Plants protect themselves, after pathogen attack, through the passive and active defense mechanisms. The passive defense mechanisms involve structural barriers or existing anti-microbial compounds which prevent colonization in the tissue, while, the active or induced defense responses include the hypersensitive response (HR) and systemic acquired resistance (SAR) i.e., production of phytoalexins and pathogenesis-related (PR) proteins, reactive oxygen species (ROS) and reactive nitrogen species (RNS) (oxidative bursts), ion fluxes across the plasma membrane, lignification and the reinforcement of the cell wall through both the cross-linking of cell wall structural proteins. The active defense responses are regulated through a complex and interconnected network of signaling pathways mediated by salicylic acid (SA), jasmonic acid (JA) and ethylene (ET).

Among the proteins induced during the plant defense, the class III plant peroxidases are well known and they play roles through (1) reinforcement of cell wall physical barriers comprising lignin, suberin, feruloylated polysaccharides and hydroxyproline-rich glycoproteins $[46,47] ;(2)$ enhanced production of reactive oxygen species as signal mediators and antimicrobial agents [48-50] ; and (3) enhanced production of phytoalexin [51].

Peroxidases have been reported to be induced by fungal infection [52,53], bacterial infection [54,55], infection caused by viruses and viroids etc. [56-59]. In tobacco, a positive correlation between peroxidase activity and resistance to tobacco wildfire disease was reported [60,61]. Furthermore, [54] have reported a rapid induction of a cationic peroxidase in rice plants, infected with Xanthomonas oryzae pv. oryzae.

\section{Wound healing}

Plants respond to wounding by activating self-defense systems to restore damaged tissues or to defend against attacks by pathogens and herbivores. Among the large number of wound-inducible proteins, peroxidase have been shown to express upon mechanical wounding in various plants, including tobacco [57,58], tomato [62], potato [62], cucumber [63], azuki bean [64], rice [65], horseradish [66] and sweet potato [67].

\section{Reactive Oxygen Species (ROS) metabolism}

The Reactive Oxygen Species (ROS) are partially reduced forms of atmospheric oxygen $\left(\mathrm{O}_{2}\right)$ and produced by the excitation of oxygen to form a singlet oxygen $\left(\mathrm{O}_{2}{ }^{1}\right)$ or from the transfer of electrons to $\mathrm{O}_{2}$, to form superoxide radical in the case of one electron; hydrogen peroxide $\left(\mathrm{H}_{2} \mathrm{O}_{2}\right)$ if two electrons are transferred; or hydroxyl radical $\left(\mathrm{OH}^{-}\right)$when three electrons have been transferred to oxygen. These reduced species of oxygen are highly reactive and are capable of oxidizing various cellular components leading to the oxidative damage of the plant cell that is associated with the peroxidation of membrane lipids, protein oxidation, enzyme inhibition and DNA damage that ultimately leads to Programmed Cell Death (PCD) [68-70]. In plant cells, ROS are produced in cell walls, chloroplasts, mitochondria, plasma membrane, 
endoplasmic reticulum, and apoplastic space [68,71]. In plants, the cellular level of $\mathrm{H}_{2} \mathrm{O}_{2}$ is mostly regulated by enzymatic actions of catalases and peroxidases. In addition to scavenging $\mathrm{H}_{2} \mathrm{O}_{2}$, the cell wall peroxidases have been considered to catalyze $\mathrm{O}_{2}^{-}$and $\mathrm{H}_{2} \mathrm{O}_{2}$ formation through oxidation of substrates such as $\mathrm{NADH}$ and IAA, in the absence of exogenous $\mathrm{H}_{2} \mathrm{O}_{2}$ [71].

\section{Auxin catabolism}

Peroxidases play an important role in auxin catabolism through the oxidative carboxylation of indole-3-acetic acid (IAA) [72]. IAA, one of the most studied plant growth regulators, is found throughout the plant, but is at highest concentrations in the apical and other meristematic regions. Auxin affects the plant development through apical dominance, cell elongation, ethylene formation and adventitious root formation. Plant peroxidases are involved in the oxidation of auxin either through the conventional $\mathrm{H}_{2} \mathrm{O}_{2}$-dependent pathway or through a $\mathrm{H}_{2} \mathrm{O}_{2}$-independent and $\mathrm{O}_{2}$-dependent pathway. As specific IAA oxygenases, the peroxidases have domains, similar to auxin-binding proteins, which are missing in non-plant peroxidases [23]

Gazaryan et al. [23] have also reported that over-expressing peroxidase in tobacco plants showed depressed IAA levels with decreased root branching and closed stomata. On the other hand, plants with suppressed peroxidase showed increased levels of IAA and rapid shoot growth, fused leaves and early flowering. Based on experimental study, Jansen et al. [73] have reported the transgenic tobacco with overexpressed peroxidase exhibited increased UV tolerance and decreased IAA levels, suggesting the contribution of the peroxidases in UV tolerance and auxin catabolism. Furthermore, Schopfer [74] have also reported the involvement of plant peroxidases in cell elongation via IAA catabolism.

\section{Seed germination}

The seed occupies a unique position and has fundamental importance in plant physiology because most of the known physiological processes are concentrated in the growth and development of the seed. The exact reaction between activation of essential enzymes, sequential release of hormones and the energy relations of the process during the germination of seed are still unknown. An increase in peroxidase activity during seed germination has been reported [75]. Fridovich [76] and Gasper et al. [77] have suggested that the peroxidase removes various toxic products from the seeds as a natural scavenger for seeds. After 4 days of germination in mung bean seedlings. Dendsay and Sachar [78] have observed a 30-fold activation of peroxidase activity. In cotton plants, increase in peroxidase activity is also correlated with auxin induced ethylene biosynthesis $[79,80]$.

\section{Fruit ripening}

Ethylene has been demonstrated as an essential plant hormone involved in initiation of fruit ripening as well as promotion of maturation and abscission of fruits and in the regulation of senescence and fading of flowers [81]. Peroxidases also contribute to the synthesis of ethylene. L- methionine is the precursor for ethylene in tissues of higher plants. Three enzymes are involved in this methioninemethional-ethylene pathway with peroxidase being most limiting enzyme in ethylene biosynthesis. Zymograms of peroxidase show change in activity pattern during initial stages fruit ripening [82]. Both positive and negative correlations between peroxidase activity and fruit ripening have been reported in literature. Thus, peroxidase activities in mango, apples, banana fruits etc. have been reported to increase with ripening [83-85] while, those of tomato, strawberry, capsicum, papaya fruits etc. decrease with ripening [86-89].

\section{Stress tolerance}

Peroxidases are considered as one of the stress indicators of plants because their level considerably increases after stress stimulation. Lignification also occurs due to stress responses [73].

The role of peroxidases and other antioxidant enzymes on heat stress have been documented by various researchers. Thus, Larkindale and Huang [90] have demonstrated that the expression level of peroxidases and superoxide dismutase increased, while those of catalase decreased after heat treatment of creeping bentgrass plants. Similarly, Edreva et al. [91] have also investigated the role of peroxidases in bean plants and they found that peroxidase activity is increased after heat treatment.

Salinity stress is caused by accumulation of dissolved salts in soil water either through natural process or due to human induced activity and the high salt accumulation in the soil can affect the growth of the plants [92,93]. Amaya et al. [94] have investigated the role of a cell wall peroxidase in the response to salt stress. They have observed the increased rates of seed germination in transgenic tobacco with overexpressed peroxidase under both osmotic and salt stress. They have also suggested that enhancement of peroxidase activity stabilizes the cell wall structure and higher germination rate might be due to the better capacity to retain water that reduces the effect of water deficit caused by the salinity. Pujari and Chanda [95] have also studied the effect of high salinity on the levels of peroxidase expression in vigna seedlings and have reported higher activity of peroxidases in salt treated plants.

Metals such as manganese $(\mathrm{Mn})$, zinc $(\mathrm{Zn})$, copper $(\mathrm{Cu})$ etc. are necessary for the plant development in trace amounts but in excess they become toxic for the plant [96]. In general, increase in peroxidase expression in response to various metals are reported and it is suggested that this increase could be a kind of defensive response for scavenging the $\mathrm{H}_{2} \mathrm{O}_{2}$ generated due to metal toxicity [97]. Assche and Clijsters [98] have reported the induction in peroxidase activity in leaves and roots treated with toxic doses of $\mathrm{Zn}, \mathrm{Cd}, \mathrm{Ni}$ and $\mathrm{Pb}$. In addition, Fang and Kao [99] have also reported the increase in peroxidases activity as well as changes in the isozyme patterns after exposure to iron, copper and zinc in rice leaves and have suggested that the toxic levels of the metals could be responsible for both quantitative and qualitative changes in the peroxidase. Abercrombie et al. [100] have also reported that in response to metals such as aluminum, arsenic, etc. the class III peroxidase genes are over expressed.

Ultraviolet-B radiation is reported to influence the plant metabolism, growth and development leading to affecting photosynthesis, flowering, pollination and transpiration by altering gene expression [101]. Jansen et al. [102-120] have analyzed various tobacco lines with altered peroxidase expression and suggested a clear link between peroxidase activity and UV tolerance. UV tolerance has been reported to be linked with levels of peroxidases in plant. Thus, Jansen et al. [73] demonstrated that UV-tolerant plants exhibited more peroxidase expression than the sensitive type.

\section{Isolation, purification, and characterization of some peroxi- dases}

Plant peroxidases from various sources such as Eruca vesicaria, tea, Ficus, lettuce, citrus, broccoli, royal palm, soybean, Leucaena leucocephala, papaya, wheat grasss, Solanum melongena, lemon etc. have been isolated, purified and characterized. A brief description of physicochemical properties of some of them is presented in Table 1. 
Citation: Pandey VP, Awasthi M, Singh S, Tiwari S, Dwivedi UN (2017) A Comprehensive Review on Function and Application of Plant Peroxidases. Biochem Anal Biochem 6: 308. doi: 10.4172/2161-1009.1000308

Page 7 of 16

\begin{tabular}{|c|c|c|c|c|c|c|c|c|}
\hline S. No. & Source & Mol. Weight & $\begin{array}{c}\mathrm{pH} \\
\text { optimum }\end{array}$ & $\begin{array}{l}\text { Temperature } \\
\text { optimum }\end{array}$ & $\begin{array}{l}\text { Km/affinity for } \\
\text { substrates }\end{array}$ & Thermostability & $\begin{array}{l}\text { Effect of metal/ } \\
\text { organic solvent }\end{array}$ & References \\
\hline 1 & Citrus jambhiri & $56 \mathrm{kDa}$ & 5.5 & $40^{\circ} \mathrm{C}$ & $\begin{array}{l}\text { Guaiacol> } \\
\text { O-dianisidine> } \\
\text { pyrogallol }\end{array}$ & $\begin{array}{c}\text { Retained } 20-30 \% \text { activity at } 50 \\
60 \text {, and } 70^{\circ} \mathrm{C} \text { after } 15,10, \text { and } \\
5 \text { min of incubation }\end{array}$ & $\begin{array}{l}\text { Inhibited by } \mathrm{Li}^{+}, \mathrm{Zn}^{2+} \\
\text { and } \mathrm{Hg}^{2+}\end{array}$ & $\begin{array}{l}\text { Mohamed, et } \\
\text { al. (2008) }\end{array}$ \\
\hline 2 & Prunus persica & $29 \mathrm{kDa}$ & 5 & $40^{\circ} \mathrm{C}$ & $\begin{array}{c}\text { o-dianisidine: } 9.35 \mathrm{mM} \\
\mathrm{H}_{2} \mathrm{O}_{2}: 15.38 \mathrm{mM}\end{array}$ & $\begin{array}{l}\text { Lost } 55 \% \text { activity at } 65^{\circ} \mathrm{C} \text { within } \\
1 \mathrm{~min}\end{array}$ & $\begin{array}{l}\text { Not affected by } \mathrm{Zn}^{2+} \\
\mathrm{Cu}^{2+}, \mathrm{Mg}^{2+}, \mathrm{Mn}^{2+}, \mathrm{NH}_{4}^{+} \\
(1.5-6.0 \mu \mathrm{M})\end{array}$ & Neves (2002) \\
\hline \multirow[b]{2}{*}{3} & \multirow[b]{2}{*}{$\begin{array}{l}\text { Lactuca sativa } \\
\qquad .\end{array}$} & \multirow[b]{2}{*}{$35 \mathrm{kDa}$} & \multirow[b]{2}{*}{5.0} & \multirow[b]{2}{*}{$45^{\circ} \mathrm{C}$} & \multirow[b]{2}{*}{$\begin{array}{l}\text { Guaiacol: } 4.74 \mathrm{mM} \\
\text { pyrogallol: } 1.96 \mathrm{mM}\end{array}$} & \multirow[b]{2}{*}{$\begin{array}{c}\text { Retained } 55 \% \text { activity at } 60^{\circ} \mathrm{C} \\
\text { after } 1 \mathrm{hr}\end{array}$} & $\begin{array}{l}\text { Inhibited by } \mathrm{Fe}^{3+} \\
\mathrm{Zn}^{2+}, \mathrm{Ca}^{2+}, \mathrm{Cu}^{2+}, \mathrm{Mn}^{2+}\end{array}$ & \multirow[b]{2}{*}{$\begin{array}{l}\text { Hu et al. } \\
(2012)\end{array}$} \\
\hline & & & & & & & $\begin{array}{l}\text { - } 40-70 \% \text { loss of } \\
\text { activity in presence of } \\
25 \% \text { propylene glycol, } \\
\text { ethanol, acetone and } \\
\text { methanol }\end{array}$ & \\
\hline 4 & Carica papaya & $240 \mathrm{kDa}$ & 7.0 & $40^{\circ} \mathrm{C}$ & $\begin{array}{c}\text { Guaiacol: } 0.8 \mathrm{mM} \\
\text { O-dianisidine: } 0.125 \\
\mathrm{mM} \text { ascorbic acid: } 5.2 \\
\mathrm{mM} \mathrm{H}_{2} \mathrm{O}_{2}: 0.25 \mathrm{mM}\end{array}$ & $\begin{array}{c}\text { Retained } 80 \% \text { activity at } 60^{\circ} \mathrm{C} \\
\text { upto } 1 \mathrm{Hr}\end{array}$ & $\begin{array}{l}\mathrm{Mg}^{2+} \text { as a potent } \\
\text { activator and } \mathrm{Ca}^{2+} \text { as a } \\
\text { weak activator }\end{array}$ & $\begin{array}{l}\text { Pandey et } \\
\text { al., (2012) }\end{array}$ \\
\hline 5 & $\begin{array}{l}\text { Roystonea } \\
\text { regia }\end{array}$ & $51 \mathrm{kDa}$ & $4-11$ & - & $\begin{array}{c}\text { o-dianisidine: } 9.35 \mathrm{mM} \\
\mathrm{H}_{2} \mathrm{O}_{2}: 15.38 \mathrm{mM}\end{array}$ & $\begin{array}{l}\text { Stable at } 70^{\circ} \mathrm{C} \text { after } 1 \mathrm{~h} \\
\text { incubation }\end{array}$ & - & $\begin{array}{l}\text { Sakharov et } \\
\text { al. (2001) }\end{array}$ \\
\hline \multirow{2}{*}{6} & \multirow{2}{*}{$\begin{array}{l}\text { Ficus } \\
\text { sycomorus }\end{array}$} & \multirow{2}{*}{$43 \mathrm{kDa}$} & \multirow{2}{*}{$5.5-7.0$} & \multirow{2}{*}{$5^{\circ} \mathrm{C}$ to $40^{\circ} \mathrm{C}$} & \multirow{2}{*}{$\begin{array}{c}\text { Guaiacol: } 9.5 \mathrm{mM} \\
\text { O-dianisidine: } 16.6 \mathrm{mM} \\
\text { pyrogallol: } 26 \mathrm{mM} \\
\mathrm{H}_{2} \mathrm{O}_{2}: 1.2 \mathrm{mM}\end{array}$} & \multirow{2}{*}{-} & $\begin{array}{l}\text { Activated by } \mathrm{Ca}^{2+} \text {, } \\
\mathrm{Ni}^{+2} \text { and } \mathrm{Mg}^{2+}\end{array}$ & \multirow{2}{*}{$\begin{array}{l}\text { Mohamed et } \\
\text { al. (2011) }\end{array}$} \\
\hline & & & & & & & $\begin{array}{r}\text { inhibited by } \mathrm{Mn}^{2+} \\
\mathrm{Fe}^{3+} \mathrm{Zn}^{2+} \text { and } \mathrm{Hg}^{2+}\end{array}$ & \\
\hline 7 & $\begin{array}{c}\text { Leucaena } \\
\text { leucocephala }\end{array}$ & $200 \mathrm{kDa}$ & 5.0 & $55^{\circ} \mathrm{C}$ & $\begin{array}{l}\text { Guaiacol: } 2.9 \mathrm{mM} \\
\mathrm{H}_{2} \mathrm{O}_{2}: 5.6 \mathrm{mM}\end{array}$ & Fully active at $65^{\circ} \mathrm{C}$ for $20 \mathrm{~min}$ & $\begin{array}{l}\text { - Activated by } \\
\mathrm{Ca}^{2+}, \mathrm{Mn}^{2+}, \mathrm{Na}^{+} \text {Azide } \\
\text { insensitive }\end{array}$ & $\begin{array}{l}\text { Pandey and } \\
\text { Dwivedi, } \\
2011\end{array}$ \\
\hline \multirow{2}{*}{8} & \multirow{2}{*}{$\begin{array}{l}\text { Eruca vesicaria } \\
\text { sbsp. Sativa }\end{array}$} & \multirow{2}{*}{$34 \mathrm{kDa}$} & \multirow{2}{*}{6.0} & \multirow{2}{*}{$40^{\circ} \mathrm{C}$} & \multirow{2}{*}{$\begin{array}{l}\text { Guaiacol: } 375.74 \mathrm{mM} \\
\text { pyrogallol: } 510.14 \mathrm{mM}\end{array}$} & \multirow{2}{*}{$\begin{array}{l}\text { Retained } 50 \% \text { activity at } 80^{\circ} \mathrm{C} \\
\text { after } 30 \text { min incubation }\end{array}$} & $\begin{array}{l}\text { Activated by } \mathrm{Ni}^{2+} \text {, } \\
\mathrm{Co}^{2+}, \mathrm{Cu}^{2+}\end{array}$ & \multirow{2}{*}{$\begin{array}{l}\text { Nadaroglu, et } \\
\text { al., (2013) }\end{array}$} \\
\hline & & & & & & & $\begin{array}{l}\cdot \quad \text { Inhibited by } \mathrm{Mn}^{2+} \\
\mathrm{Hg}^{2+}, \mathrm{Zn}^{2+}, \mathrm{K}^{+}, \mathrm{Ca}^{2+}, \mathrm{Fe}^{2+}\end{array}$ & \\
\hline \multirow{2}{*}{9} & \multirow{2}{*}{ Citrus medica } & \multirow{2}{*}{$32 \mathrm{kDa}$} & \multirow{2}{*}{6.0} & \multirow{2}{*}{$50^{\circ} \mathrm{C}$} & \multirow{2}{*}{$\begin{array}{c}\text { Guaiacol: } 8 \mathrm{mM} \\
\text { o-dianisidine : } 1.8 \mathrm{mM} \\
\mathrm{H}_{2} \mathrm{O}_{2}: 0.66 \mathrm{mM}\end{array}$} & \multirow{2}{*}{ Stable at $60^{\circ} \mathrm{C}$ and $65^{\circ} \mathrm{C}$} & $\begin{array}{r}\text { Activated by } \mathrm{Cu}^{2+}, \\
\mathrm{Co}^{2+}, \mathrm{Mg}^{2+}, \mathrm{K}^{+} \text {and } \mathrm{Ca}^{2+}\end{array}$ & \multirow{2}{*}{$\begin{array}{l}\text { Mall et al. } \\
(2013)\end{array}$} \\
\hline & & & & & & & - $\begin{array}{r}\text { Inhibited by } \mathrm{Hg}^{2+} \text {, } \\
\mathrm{Fe}^{2+}, \mathrm{Mn}^{2+} \text { and } \mathrm{Zn}^{2+}\end{array}$ & \\
\hline 10 & $\begin{array}{l}\text { Fragaria } \\
\text { ananassa } \\
\text { Duch. }\end{array}$ & $56 \mathrm{kDa}$ & 6.0 & $30^{\circ} \mathrm{C}$ & - & $\begin{array}{c}\text { Complete loss of activity }>60^{\circ} \mathrm{C} \\
\text { within } 5 \mathrm{~min}\end{array}$ & - & $\begin{array}{l}\text { Civello et al. } \\
\quad(1995)\end{array}$ \\
\hline 11 & $\begin{array}{l}\text { Brassica } \\
\text { oleracea Var. } \\
\quad \text { Italica }\end{array}$ & $\begin{array}{c}\text { Neutral and } \\
\text { basic: } 43 \mathrm{kDa} \\
\text { Acidic: } 48 \mathrm{kDa}\end{array}$ & $\begin{array}{c}\text { Neutral and } \\
\text { basic : } 6.0 \\
\text { Acidic: } 4.0\end{array}$ & - & $\begin{array}{c}\text { Guaiacol: } 0.305 \mathrm{mM} \\
\text { (acidic), } 8.789 \mathrm{mM} \\
\text { (basic), } 0.711 \mathrm{mM} \\
\text { (neutral) }\end{array}$ & $\begin{array}{c}\text { Stable at } 80^{\circ} \mathrm{C} \text { activity after } 1 \mathrm{hr} \\
\text { incubation }\end{array}$ & - & $\begin{array}{l}\text { Thongsook } \\
\text { and Barrett, } \\
\text { (2005) }\end{array}$ \\
\hline & & & & & & & $\begin{array}{r}\text { Activated by } \mathrm{Na}^{+} \\
\mathrm{Zn}^{2+}, \mathrm{Mg}^{2+}, \mathrm{Ca}^{2+} \text { and } \\
\mathrm{Mn}^{2+}\end{array}$ & \\
\hline 12 & Citrus limon & $200 \mathrm{kDa}$ & 5.0 & $40^{\circ} \mathrm{C}$ & Guaiacol: $0.7 \mathrm{mM}$ & Retained $92 \%$ activity at $80^{\circ} \mathrm{C}$ & $\begin{array}{r}\text { tolerance towards } \\
\mathrm{Cd}^{2+}, \mathrm{Cs}^{2+} \text { and } \mathrm{Ni}^{2+} \\
\end{array}$ & Pandey, et \\
\hline 12 & 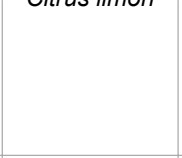 & $\angle 00 \mathrm{nLa}$ & 0.0 & 400 & $\mathrm{H}_{2} \mathrm{O}_{2}: 1.09 \mathrm{mM}$ & for $1 \mathrm{~h}$ & $\begin{array}{c}\text { Retained } 30- \\
50 \% \text { activity in the } \\
\text { presence of } 50 \% \\
\text { ethanol, methanol and } \\
\text { isopropanol }\end{array}$ & al., (2016) \\
\hline & $\begin{array}{l}\text { Actinidia } \\
\text { deliciosa }\end{array}$ & $29 \mathrm{kDa}$ & 5.5 & $50^{\circ} \mathrm{C}$ & $\begin{array}{c}\text { Guaiacol: } 7.4 \mathrm{mM} \mathrm{H}_{2} \mathrm{O}_{2}: \\
1.3 \mathrm{mM}\end{array}$ & & - & $\begin{array}{l}\text { Soda et al., } \\
\text { (1991) }\end{array}$ \\
\hline 14 & $\begin{array}{l}\text { Camellia } \\
\text { sinensis }\end{array}$ & $34.5 \mathrm{kDa}$ & 4.5 to 5.0 & - & $\begin{array}{c}\text { Pyrogallol > ascorbate } \\
>\text { guaiacol }\end{array}$ & - & - & $\begin{array}{l}\text { Kvaratskhelia } \\
\text { et al. (1997) }\end{array}$ \\
\hline 15 & $\begin{array}{l}\text { Solanum } \\
\text { tuberosum }\end{array}$ & $45.8 \mathrm{kDa}$ & 4.5 & $40^{\circ} \mathrm{C}-60^{\circ} \mathrm{C}$ & - & - & - & $\begin{array}{l}\text { Bernards et } \\
\text { al. (1999) }\end{array}$ \\
\hline 16 & $\begin{array}{c}\text { Trachyca-rpus } \\
\text { fortunei }\end{array}$ & $50 \mathrm{kDa}$ & 3.0 & $61-67^{\circ} \mathrm{C}$ & - & Moderate stable & $\begin{array}{l}\text { Inhibited by } \mathrm{Na}^{+}, \mathrm{Ca}^{++} \\
\text {and } \mathrm{Mg}^{++}\end{array}$ & $\begin{array}{l}\text { Caramyshve } \\
\text { et al., (2006) }\end{array}$ \\
\hline 17 & $\begin{array}{l}\text { Solanum } \\
\text { melongena }\end{array}$ & - & 5.5 & $84^{\circ} \mathrm{C}$ & $\begin{array}{l}\text { Guaiacol: } 6.5 \mathrm{mM} \\
\mathrm{H}_{2} \mathrm{O}_{2}: 0.33 \mathrm{mM}\end{array}$ & - & - & $\begin{array}{c}\text { Vernwal et al. } \\
(2006)\end{array}$ \\
\hline 18 & $\begin{array}{l}\text { Fagopyrum } \\
\text { esculentum }\end{array}$ & $\begin{array}{l}46.1 \mathrm{kDa} \\
\text { (POX I) and } \\
58.1 \mathrm{kDa} \\
\text { (POX II). }\end{array}$ & $\begin{array}{l}8.0(\mathrm{POX} I) \\
4.5(\mathrm{POX} I \mathrm{I})\end{array}$ & $\begin{array}{l}30^{\circ} \mathrm{C}(\mathrm{POX} \\
\text { I) and } 10^{\circ} \mathrm{C} \\
(\mathrm{POX} I \mathrm{II})\end{array}$ & $\begin{array}{c}\text { POX I- } \\
\text { Guaiacol: } 0.288 \mathrm{mM} \text {, } \\
\text { o-dianisidine: } 0.229 \\
\text { mM, Ascorbate: } \\
\text { 0.043 mM POX II- } \\
\text { o-dianisidine: } 0.137 \\
\text { mM, Ascorbate: } 0.029 \\
\text { mM }\end{array}$ & - & - & $\begin{array}{l}\text { Suzuki et al. } \\
\qquad(2006)\end{array}$ \\
\hline
\end{tabular}




\begin{tabular}{|c|c|c|c|c|c|c|c|c|}
\hline \multirow{2}{*}{19} & \multirow{2}{*}{$\begin{array}{l}\text { Gossyp-ium } \\
\text { hirsutum }\end{array}$} & \multirow{2}{*}{$\begin{array}{c}39.1 \text { and } 64 \\
\mathrm{kDa}\end{array}$} & \multirow{2}{*}{5.0 and 6.0} & \multirow{2}{*}{$25^{\circ} \mathrm{C}$} & \multirow{2}{*}{-} & \multirow{2}{*}{-} & 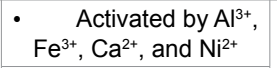 & \multirow{2}{*}{$\begin{array}{l}\text { Kouakou et } \\
\text { al., (2009) }\end{array}$} \\
\hline & & & & & & & - $\begin{array}{r}\text { Inhibited by } \mathrm{Mn}^{2+}, \\
\mathrm{K}^{+}, \mathrm{Zn}^{2+} \text { and } \mathrm{Hg}^{2+}\end{array}$ & \\
\hline 20 & Vigna species & - & - & - & $\begin{array}{c}\text { o-dianisidine: } 1.55-2.24 \\
\mathrm{mM}\end{array}$ & $\begin{array}{c}\text { Retained } 33 \%, 66 \% \text { and } 3.4 \% \\
\text { activity at } 70^{\circ} \mathrm{C}, 75^{\circ} \mathrm{C} \text { and } \\
80^{\circ} \mathrm{C} \text {, for } 1 \mathrm{~h}\end{array}$ & - & $\begin{array}{l}\text { Yves et al. } \\
\text { (2011) }\end{array}$ \\
\hline 21 & $\begin{array}{l}\text { Brassica } \\
\text { oleracea }\end{array}$ & - & 4.0 & - & - & $\begin{array}{c}\text { Retained }<10 \% \text { activity after } 5 \\
\text { min at } 76.6^{\circ} \mathrm{C}\end{array}$ & - & $\begin{array}{l}\text { Fortea, et al., } \\
(2012)\end{array}$ \\
\hline 22 & $\begin{array}{c}\text { Luffa aegyptia- } \\
\text { ca }\end{array}$ & - & 6.5 & $60^{\circ} \mathrm{C}$ & $\begin{array}{l}\text { Guaiacol: } 2.0 \mathrm{mM} \\
\mathrm{H}_{2} \mathrm{O}_{2}: 0.2 \mathrm{mM}\end{array}$ & - & - & $\begin{array}{l}\text { Yadav et al., } \\
\text { (2011) }\end{array}$ \\
\hline
\end{tabular}

Table 1: Physicochemical properties of some purified plant peroxidases.

\section{Applications of peroxidases}

Peroxidases are important from the point of view of their industrial applications by virtue of their ability to catalyze the oxidationreduction reaction of a wide range of phenolic as well as non-phenolic substrates in the presence of hydrogen peroxide. A number of industrial applications of peroxidases have been reported in the area of agriculture, analytical, environmental, medical sectors etc. Thus, peroxidases have been used in bioremediation of contaminating environmental pollutants such as phenols, delignification in paper and pulp industry, diagnosis kit development, immunoassay, organic and polymer synthesis as well as in and biosensor technology. They are also used for developing convenient and quick methods for the determination and quantification of hydrogen peroxide in both the biological and industrial samples $[121,122]$. Additional applications of peroxidases include determination of extent of lipid peroxidation in meat food products, in polymerization and precipitation of aqueous phenols as well as in decolorization of industrial effluents [123]. Some of the important applications of peroxidases are described in detail in following sections.

\section{Application as biosensor}

Biosensors have significance in medicine, quality control, food and environmental monitoring as well as in research. Enzyme based biosensors have advantageous over other analytical techniques with regards to high selectivity and high sensitivity. The performance of these biosensors depends upon the amount and bioactivity of enzyme immobilized onto the electrodes. Peroxidases have immense potential and wide spread application as biosensors [123].

Horse radish peroxidase has widely been used in development of biosensors [124-126]. HRP biosensors are made by applying various detection methods including an amperometric immunosensor, mass balance, potentiometric methods, photovoltaic spectroscopy, optical and chemiluminescent methods etc. [127-132]. Potentiometric based biosensors are developed by combination of an enzyme (eg. peroxidase) and a transducer that can detect the variation in protons. Glucose, maltose or lactate are reported to be detected by peroxidase based biosensor using potentiometric methods [133]. HRP-based biosensors for antioxidant monitoring have been applied in the detection of superoxide radical [134], nitric oxide [135], glutathione [134,136], uric acid $[137,138]$ and phenolic compounds [139-141]. Besides HRP, other plant peroxidases such as sweet potato, tobacco, peanut, soybean etc. have been also explored for their applications as biosensors. The sweet potato peroxidase, due to its easy availability, high specific activity and superior electrochemical characteristics, is considered as advantageous for application as biosensor [126]. A recombinant tobacco peroxidase immobilized to graphite electrodes were reported to be advantageous for detection of aromatic phenols and amines [142].

Soybean peroxidase (SBP) has been reported to be advantageous over HRP for the biosensor manufacturing. The first SBP biosensor was reported by Vreeke et al. [143] as a thermostable-wired enzyme electrode. Spring cabbage peroxidase (SCP), has been reported to provide a good bioelectrocatalytic system due to its good affinity for various substrates, stability towards temperature and $\mathrm{pH}$ and ability to bind to polyanionic matrices and low costs of extraction and purification [144]. Due to efficient bioelectrocatalysis of lignin peroxidases (LiP), the LiP-graphite electrode biosensor systems have been developed for detection of recalcitrant aromatic compounds [145].

\section{Application in analytical and diagnostic kits}

Peroxidases are widely used in the development of analytical as well as diagnostic kits. Among peroxidases, horseradish peroxidases are most commonly used for the analytical purposes [146]. However, other plant peroxidases having wide $\mathrm{pH}$ and temperature stability are emerging as option for HRP. Since, the peroxidase has capability to produce stable chromogenic products, thus, they are suitable candidate enzyme for the manufacturing of various diagnostic kits based on enzyme conjugated antibody technology [147]. Uric acid detection kits have been developed using turnip root peroxidases [148].

In combination with cholesterol oxidase and cholesterol esterase, peroxidases have also been exploited for developing cholesterol detection kits that help in quantification and monitoring of human serum cholesterol $[149,150]$. Peroxidases have been used in developing kits for the diagnosis of bladder and prostate cancers through the detection of 8-hydroxydeoxyguanosine and its analogs in urine [151]. The monitoring of glucose for diabetes mellitus and of lactate in hypoxia and ischemia, are of great significance in patient management [152] and it would be highly desirable to develop such a sensitive biosensor for the detection of $\mathrm{H}_{2} \mathrm{O}_{2}$, which would be stable at $37^{\circ} \mathrm{C}$ and higher temperatures for sustained periods of time. Lactose content monitoring strips have been developed using the combination of immobilized $\beta$-galactosidase, galactose oxidase and HRP enzymes [153]. In biomedical sectors, for cancer treatment gene-directed enzyme/prodrug therapy, (GDEPT) have been extensively and successfully used. Greco et al. [154] proposed a prompt and efficient peroxidase-IAA based GDEPT system for cancer treatment. This enzyme-prodrug system has been found to be effective against hypoxic and anoxic tumor cells and also has potential to be used in other anti-cancer strategies. Besides GDEPT, in antibody-directed enzyme/ prodrug therapy (ADEPT), specific HRP-conjugated antibodies are used $[155,156]$. Influenza virus was reported to detect using ultrasensitive colorimetric immunoassay with peroxidase-mimic of gold nanoparticles [157].

\section{Application in de-colorization of industrial dyes}

Dyes are used extensively for paper printing, color photography and as additive in petroleum products. These are synthetic aromatic 
compounds having complex structures, biologically un-degradable and causing environmental problems. For the degradation of theses synthetic industrial dyes, the currently available methods such as chemical oxidation, reverse osmosis, and adsorption, are highly efficient, but they suffer with some disadvantages. Now- a-days the interest is towards the use of microbial degradation of dyes, because this process is less expensive and ecofriendly alternative [158]. Enzymes such as lignin peroxidases (LiPs) and manganese peroxidases (MnPs), are involved in the decolorization of synthetic azo dyes such as orange II, and others [159]. Horseradish peroxidase (HRP) is reported to degrade phenol and substituted phenols via a free radical polymerization mechanism and can be effective in degrading and precipitating industrially important azo dyes, such as Remazol $[160,161]$. The properties of white-rot fungi to oxidize various recalcitrant xenobiotics released to the environment are thought to result from the activities of $\mathrm{LiP}, \mathrm{MnP}$, and laccases [162]. A purified peroxidase produced by Geotrichum candidum dec 1 , was involved in decolorization of dyes [163]. Pandey et al. [164,165] have also reported that the purified lemon peroxidase was found to be oxidized the industrial dyes in the order of aniline blue $>$ methyl orange $>$ indigo carmine $>$ trypan blue $>$ crystal violet.

The textile industry, being one of the traditional industrial segments, consume large quantities of water, chemical products and synthetic dyes and generate large volumes of wastewater that contain a high organic load that are responsible for acute or chronic toxicity on the ecosystems. Thus, the wastewater from textile industries is considered as one of the most polluting among all industrial wastes, thereby requiring appropriate treatment technologies. Peroxidases have been shown to have great potential in the decolorization process to decrease textile industry pollutant residues [166,167]. Uses of peroxidases, such as horseradish, Brassica campestres turnip, tomato, bitter gourd, soybean, Ipomea palmata and Saccharum spontaneum peroxidases, for degrading and detoxifying polyaromatic hydrocarbons, polychlorinated biphenyls, and other synthetic industrial dyes have been reported [168-178].

\section{Application in bioremediation of phenolic compounds}

Aromatic compounds such as phenols and its derivatives are a major class of pollutants in wastewater from a number of food and chemical industries [179]. Phenols are known to be toxic and also hazardous carcinogens that can accumulate in the food chain. Being highly toxic their discharge into the environment should be highly regulated [180]. The polymerization using redox enzymes is one of the phenol removal methods. The enzyme treatment offers a high degree of specificity, operation under mild conditions and high reaction velocity [180] concomitant with an ecofriendly approach. The ability of peroxidases to catalyze the formation of free-radical from various aromatic pollutants and their polymerization can be potentially exploited in bioremediation and wastewater treatment. Thus, peroxidases have been reported for removal of phenolic compounds from synthetic model effluents and also from real industrial effluents [160,161,181-183]. There are a number of reports in literature on detoxification of wastewater contaminated with phenols, cresols, and chlorinated phenols using HRP. Using HRP, Bewtra et al. [184] have determined the optimum $\mathrm{pH}$ for removal of 2, 4-dichlorophenol as 6.5. The removal efficiency is also affected by the hydrogen peroxide concentration. Soybean and turnip peroxidases have also been shown to have good potential for removal of phenolics compounds $[185,171]$. Additives, such as PEG or gelatin, usually improve removal efficiency by protecting the enzyme [186]. The addition of PEG-3350 or PEG8000 to soybean peroxidase, increased the removal efficiency of 2 , 4 -dichlorophenol by a factor of 10 or 50 , respectively [187]. Thus, the potential of peroxidase for soil and water detoxification constitute a possible basis for the development of bioremediation technologies.

\section{Application in pulp and paper industry}

Lignin, a phenolic heteropolymer, shows negative impact on the proper exploitation of plant biomass for the pulp and paper industry. Thus, the lignin should be removed prior to the production of good quality paper. The chemical delignification leads to production of various pollutants. Thus, the enzymatic degradation of lignin is suggested as a better alternative. Lignin peroxidase (LiP) and manganese peroxidase $(\mathrm{MnP})$ are successfully used for biopulping, biobleaching as well as selective delignification in the paper industry and selective delignification helps in the production of cellulosic materials that can be used as efficient feed and biofuel $[188,189]$.

\section{Hair dyeing}

Traditionally the hair coloring dyes are synthesized via oxidative polymerization of dye precursors (phenols or aminophenols, and couplers). For this process, the hydrogen peroxide (3\%) is used that initiates the polymerization reaction but it bleaches the natural hair pigment melanin. These concentrations of $\mathrm{H}_{2} \mathrm{O}_{2}$, when applied repeatedly, can cause hair damage. To achieve a gentler dyeing with milder oxidation process, the enzymes such as oxidases, peroxidases etc. have been proposed as better options [190].

\section{Analytical applications}

Enzyme Linked Immunosorbent Assays (ELISA) has advantages over other immunoassays in simplicity, low cost, reliability, simple equipment requirement etc. ELISA is usually developed to detect antigens or antibodies by producing an enzyme such as peroxidase catalyzed color changes. In these assays an enzyme-linked antibody specific to the antigen is required along with a chromogenic substrate, which give colored product in the presence of the enzyme and the color of the product is proportional to the amount antigen/antibody of interest. For such type of assays HRPs are the most commonly used enzymes as linked with antibody. They are used to screen the monoclonal antibodies against dangerous mycotoxins of various fungal species like Aspergillus, Penicillium (ochratoxins), Fusarium (T-2 toxin, trichothecenes) etc [191-193]. A large number of reports regarding the development of enzyme immunoassays using peroxidase as reporter enzyme to detect toxins, pathogens, and other analyses are available. For example, in detection of Goynyautoxins, Chlamydia, Fusarium toxin, Dengue virus proteins, Hepatitis-E virus peroxidases are used [194-199]. HRP-based immunoassays for the detection of undeclared milk proteins (eg. bovine b-lactoglobulin) in foods has also been developed [200].

The DNA detection using complementary DNA probes is of significance in diagnostics and research. The non-radioactive DNA probes associated with peroxidases, such as HRP have become safer than radioactive probes [201]. Peroxidases have been reported to become suitable for microarray analyses because it catalyses a large number of electron-transfer reactions with natural and synthetic substrates. It can be used either directly immobilized on the microarray [202], or as a labeling agent for nucleic acids, antibodies and other proteins [203,204]. The HRP-based or associated microarrays (biochips) have been used in various applications such as expression analysis, recombination and gene mapping, mutation analysis etc $[205,206]$.

\section{Application in organic polymer synthesis and grafting}

The importance of heme peroxidases in polymer chemistry is 
based on their ability to oxidize a variety of phenolic molecules thereby generating reactive species (phenoxy radicals) which provide ideal sites for cross-linking (coupling) leading to polymerization reactions. The grafting application of peroxidase is one of the important industrial applications of heme peroxidases. The free radicals generated from the reactions catalyzed by peroxidases, can induce formation of other new functional polymers such as phenolic resins $[207,208]$. The broad spectrum of peroxidase applications in organic synthesis is due to their ability to catalyze different types of reactions as 1) oxidative dehydrogenations $\left(2 \mathrm{RH}+\mathrm{H}_{2} \mathrm{O}_{2} \rightarrow 2 \mathrm{R}^{\circ}+2 \mathrm{H}_{2} \mathrm{O}\right)$, 2) oxygen transfer reactions $\left.\left(\mathrm{R}+\mathrm{H}_{2} \mathrm{O}_{2} \rightarrow \mathrm{RO}+\mathrm{H}_{2} \mathrm{O}\right), 3\right)$ oxidative halogenations $(\mathrm{RH}+$ $\left.\mathrm{H}_{2} \mathrm{O}_{2}+\mathrm{HX} \rightarrow \mathrm{RX}+2 \mathrm{H}_{2} \mathrm{O}\right)$ and 4$) \mathrm{H}_{2} \mathrm{O}_{2}$ dismutation $\left(2 \mathrm{H}_{2} \mathrm{O}_{2} \rightarrow 2 \mathrm{H}_{2} \mathrm{O}+\right.$ $\mathrm{O}_{2}$ ) $[209,210]$. The peroxidases have been used in the development of hybrid resins from renewable sources to replace phenol-formaldehyde based resins that are widely used in surface coatings, adhesives, laminates, molding, friction materials, abrasives, flame retardants, carbon membranes, glass fiber laminates, fiberboards, and proteinbased wood adhesives etc [211].

Blinkovsky and Dordick [212] have demonstrated the HRP mediated polymerization of phenolics and incorporation of phenols into lignin leading to the formation of polymers of great potential as phenolic resins [213]. For example, enzymatically synthesized poly (p-phenylphenol) and poly (p-cresol) were reported to have high melting points, whereas, the poly (p-phenyl-phenol) exhibited higher electrical conductivity than that of phenol-formaldehyde based resins. The incorporation of cresol into lignin by peroxidase provides a platform for using lignin as a raw material for grafting molecules to obtain new functional polymers [214]. Thus, the ability of peroxidases to modify lignin and develop new functional polymers with excellent properties leads to the progress in lignin applications such as in development of polymer adhesives, biodegradable plastics, polyurethane copolymers, paints, dispersants in dyes, in pesticides, and printed circuit boards [207,215-217]. Using Soybean peroxidase (SBP), Ikeda et al. [218] successfully developed polyphenol resins without involvement of formaldehyde, which exhibited better properties than that of conventionally polymerized resins.

Kim et al. [219] have used SBP to catalyze the oxidative polymerization of cardanol to polycardanol. Cardanol is an excellent raw material for the preparation of high grade insulating varnishes, paints, enamels, laminating resins, and rubber. Thus, the cardanolbased resins show resistance towards softening action of mineral oils, acids and alkaline conditions, termite, and insects and have coefficient of friction less sensitive to temperature changes than phenolformaldehyde based resins.

The free radical polymerization of methyl methacrylate (MMA) catalyzed by peroxidase (such as HRP) was developed by Karla and Gross [220]. Poly (methyl methacrylate) (PMMA) is a colorless polymer used extensively for the production of scratch resistance optical products, plastics, and PVCs. In addition, peroxidase mediated polymerization of acrylamide in to poly-acrylamide with good thermal properties have been reported [221-223]. Peroxidases have also been used to catalyse the free-radical polymerization of vinyl monomers, such as acrylamide, acrylic acid and methacrylates, such as methyl, phenylethyl, 2-hydroxyethyl methacrylate $[220,224]$. MnP also reported to catalyze the polymerization of acrylamide into a thermoplastic resin namely polyacrylamide in the presence of 2, 4-pentanedione, has been reported [225]. With the versatile properties of peroxidases, styrene was also polymerized into polystyrene that is widely used as packaging material, injection molded parts, UV screening agents, in disposable cutlery, and CD and DVD cases [226].
The chemical synthesis of conducting polymers such as polyaniline, the most extensively studied conducting polymers having high environmental stability and promising electronic application including electronic equipment, photovoltaic cells, plastic batteries, polymer light-emitting diodes, and optical displays, is not eco-friendly, thus HRP have been tried as an alternative for the synthesis [227-234]. But due to low activity of HRP towards the synthesis of Polyaniline, the other anionic peroxidase purified from soybean, african oil palm tree is developed as better substitute of HRP [235].

Peroxidase catalyzed polymerization of substituted and unsubstituted phenols and anilines have also been reported as better and striking alternative to the conventional chemical (formaldehyde) polymerization method [236-238]. Peroxidases also catalyze the stereospecific oxygen transfer reactions such as heteroatom oxidations, oxidation of $\mathrm{C}-\mathrm{H}$ bonds in allylic/benzylic compounds, alcohols and indoles that yield various synthetic compounds of significance [210]. The plant peroxidases have also been shown to have application in the synthesis of $\alpha$ - 3', 4'-anhydrovinblastine, by the coupling reaction of catharanthine and vindoline. The $\alpha-3$ ', 4'-anhydrovinblastine is a metabolic precursor of vinblastine and vincristine which are used in cancer chemotherapy $[238,239,240]$.

\section{Conclusion}

Peroxidases catalyze oxidation of a wide range of phenolic as well as non-phenolic compounds. Plant peroxidases, belonging to class III peroxidases, have been implicated in various plant growth and developmental processes such as cell wall metabolism, fruit growth and ripening, metabolism of reactive oxygen species (ROS), defense against pathogens etc. In view of the wide applications of peroxidases in key areas such as clinical biochemistry, immunology, biotechnology, environment and industry, they are considered as one of the important industrial enzyme. Thus, peroxidases have been used in bioremediation of contaminating environmental pollutants such as phenolic compounds, delignification in paper and pulp industry, diagnosis kit development, immunoassay, organic and polymer synthesis as well as in ELISA and biosensor technology. Furthermore, with the potentials of nano-based biosensor applications, in recent years, peroxidases have gained more prominence. The use of immobilized enzymes, in various industrial processes, is one of the advancement in their application. For all such applications of peroxidases there is a need for search of novel peroxidases offering tolerance towards the factors / ingredients of the reaction environment such as temperature, $\mathrm{pH}$, salts, metals and organic solvents etc.

\section{Acknowledgements}

Financial assistances from Department of Biotechnology (DBT), New Delh under Bioinformatics Infrastructure Facility; Department of Higher Education, Government of U.P., Lucknow under Centre of Excellence Grant and Department of Science and Technology, New Delhi under Promotion of University Research and Scientific Excellence (DST-PURSE) programme for infrastructure development are gratefully acknowledged.

\section{References}

1. Passardi F, Theiler G, Zamocky M, Cosio C, Rouhier N, et al. (2007) PeroxiBase: The peroxidase database. Phytochem 68: 16051611

2. Passardi F, Zamocky M, Favet J, Jakopitsch C, Penel C, et al. (2007) Phylogenetic distribution of catalase-peroxidases: are these patches of order in chaos? Gene 397:101-113

3. Zamocky M, Obinger C (2010) Molecular phylogeny of heme peroxidases. In Biocatalysis based on heme peroxidases. Torresl E, Ayala M (Edn) Springer, Heidelberg Dordrecht, London, New York.

4. So'derhall K (1999) Invertebrate immunity. Dev Comp Immunol 23: 263-266. 
Citation: Pandey VP, Awasthi M, Singh S, Tiwari S, Dwivedi UN (2017) A Comprehensive Review on Function and Application of Plant Peroxidases. Biochem Anal Biochem 6: 308. doi: 10.4172/2161-1009.1000308

5. Dick GJ, Podell S, Johnson HA, Rivera-Espinoza $Y$, Bernier-Latmani $R$, et al. (2008) Genomic insights into Mn (II) oxidation by the marine alpha proteobacterium Aurantimonas sp. strain SI85-9A1. Appl Environ Microbiol 74 2646-2658.

6. Passardi F, Bakalovic N, Teixeira FK, Pinheiro-Margis M, Penel C, et al. (2007) Prokaryotic origins of the peroxidase superfamily and organellar-mediated transmission to eukaryotes. Genomic 89: 567-579.

7. Shigeoka S, Ishikawa T, Tamoi M, Miyagawa Y, Takeda T, et al. (2002) Regulation and function of ascorbate peroxidase isoenzymes. J Exp Bot 53: 1305-1319.

8. Skulachev VP (1998) Cytochrome C in the apoptotic and antioxidant cascades FEBS Letters 423: 275-280.

9. Sharp KH, Mewies M, Moody PCE, Raven EL (2003) Crystal structure of the ascorbate peroxidase-ascorbate complex. Nat Str Biol 10: 303-307.

10. Kangasjärvi S, Lepistö $A$, Hännikäinen K, Piippo $M$, Luomala EM, et al (2008) Diverse roles for chloroplast stromal and thylakoid-bound ascorbate peroxidases in plant stress responses. Biochem J 412: 275-285.

11. Bernroitner M, Zamocky M, Furtm€uller PG, Peschek GA, Obinger C (2009) Occurrence, phylogeny, structure, and function of catalases and peroxidases in cyanobacteria. J Exp Bot 60: 423-440.

12. Smulevich G, Jakopitsch C, Droghetti E, Obinger C (2006) Probing the structure and bifunctionality of catalase-peroxidase (KatG). J Inorg Biochem 100: $568-585$.

13. Yamada Y, Fujiwara T, Sato T, Igarashi N, Tanaka N (2002) The $2.0 \AA$ crystal structure of catalase-peroxidase from Haloarcula marismortui. Nat Struct Biol 9: 691-695.

14. Piontek K, Smith AT, Blodig W (2001) Lignin peroxidase structure and function Biochem Soc Trans 29:111-116.

15. Pérez-Boada M, Ruiz-Dueñas FJ, Pogni R, Basosi R, Choinowski T, et al. (2005) Versatile peroxidase oxidation of high redox potential aromatic compounds: site-directed mutagenesis, spectroscopic and crystallographic investigation of three long-range electron transfer pathways; J Mol Biol 354: 385-402.

16. Martinez M, Ruiz-Duenas FJ, Guillen F, Martinez AT (1996) Purification and catalytic properties of two manganese peroxidase isoenzymes from Pleurotus eryngii. Eur J Biochem 237: 424-432.

17. Tognolli M, Penel C, Greppin H, Simon P (2002) Analysis and expression of the class III peroxidase large gene family in Arabidopsis thaliana. Gene 288 129-138.

18. Hiraga S, Sasaki K, Ito H, Ohashi Y, Matsui H (2001) A large family of class II plant peroxidases. Plant Cell Physiol 42: 462-468.

19. Cosio C, Dunand C (2009) Specific functions of individual class III peroxidase genes. J Exp Bot 60: 391-408.

20. Passardi F, Penel C, Dunand C (2004) Performing the paradoxical: how plant peroxidases modify the cell wall. Trends Plant Sci 9: 534-540.

21. Barceló AR, Pomer F (2001) Oxidation of cinnamyl alcohols and aldehydes by a basic peroxidase from lignifying Zinnia elegans hypocotyls. Phytochem 57 $1105-1113$

22. Bernards MA, Fleming WD, Llewellyn DB, Priefer R, Yang X, et al. (1999) Biochemical characterization of the suberization-associated anionic peroxidase of potato. Plant Physiol 121:135-146.

23. Gazaryan IG, Lagrimini LM, Ashby GA, Thorneley RN (1996) Mechanism of indole-3-acetic acid oxidation by plant peroxidases: anaerobic stopped-flow spectrophotometric studies on horseradish and tobacco peroxidases. Biochem J 313: 841-847.

24. Allison SD, Schultz J (2004) Differential activity of peroxidase isozymes in response to wounding, gypsy moth and plant hormones in northern red oak. J Chem Ecol 30: 1363-1379.

25. Liszkay A, Kenk B, Schopfer P (2003) Evidence for the involvement of cell wall peroxidase in the generation of hydroxyl radicals mediating extension growth. Planta 217: 658-667.

26. Mc Innis SM, Desikan R, Hancock JT, Hiscock SJ (2006) Production of reactive oxygen species and reactive nitrogen species by angiosperm stigmas and pollen: potential signalling crosstalk? New Phytologist 172: 221-228.
27. Huang R, Xia R, Hu L, Lu Y, Wang M (2007) Antioxidant activity and oxygenscavenging system in orange pulp during fruit ripening and maturation. Sci Hortic 113: 166-172.

28. Bindschedler LV, Dewdney J, Blee KA, Stone JM, Asai T, et al. (2006) Peroxidase-dependent apoplastic oxidative burst in Arabidopsis required for pathogen resistance. Plant J 47: 851-863.

29. Welinder KG, Justesen AF, Kjaersgard IV, Jensen RB, Rasmussen SK, et al. (2002) Structural diversity and transcription of class III peroxidases from Arabidopsis thaliana. Eur J Biochem 269: 6063-6081.

30. Passardi F, Longet D, Penel C, Dunand C (2004) The class III peroxidase multigenic family in rice and its evolution in land plants. Phytochem 65: 18791893

31. Singh S, Pandey VP, Naaz H, Dwivedi UN (2012) Phylogenetic analysis, molecular modeling, substrate-inhibitor specificity, and active site comparison of bacterial, fungal, and plant heme peroxidases. Biotechnol Appl Biochem 59: 283-294.

32. Nissum M, Feis A, Smulevich G (1998) Characterization of soybean seed coat peroxidase: Resonance Raman evidence for a structure-based classification of plant peroxidases. Biospectroscopy 4: 355-364.

33. Poulos TL, Kraut J (1980) The stereochemistry of peroxidase catalysis. J Bio Chem 255: 8199-8205.

34. Henriksen A, Smith AT, Gajhede M (1999) The structures of the horseradish peroxidase $\mathrm{C}$-ferulic acid complex and the ternary complex with cyanide suggest how peroxidases oxidize small phenolic substrates. J Biol Chem 274 35005-35011.

35. Goodwin DC, Grover TA, Aust SD (1997) Roles of efficient substrates in enhancement of peroxidase-catalyzed oxidations. Biochem 36: 139-147.

36. Passardi F, Cosio C, Penel C, Dunand C (2005) Peroxidases have more functions than a Swiss army knife. Plant Cell Rep 24: 255-265.

37. El-Mansouri I, Mercado JA, Santiago-Domenech N, Pliego-Alfaro F, Valpuesta $\mathrm{V}$, et al. (1999) Biochemical and phenotypical characterization of transgenic tomato plants overexpressing a basic peroxidase. Physiol Plant 106: 355-362.

38. Christensen JH, Bauw G, Welinder KG, Montagu MV, Boerjan W (1998) Purification and characterization of peroxidases correlated with lignification in Poplar xylem. Plant physiol 118: 125-135.

39. Mader M, Anberg-Fisher V (1982) Role of peroxidase in lignification of tobacco cells : I. Oxidation of Nicotinamide Adenine Dinucleotide and Formation of Hydrogen Peroxide by Cell Wall Peroxidases. Plant physiol 70: 1128-1131.

40. Andrews J, Adams SR, Burton KS, Evered CE (2002) Subcellular localization of peroxidase in tomato fruit skin and the possible implications for the regulation of fruit growth. J Exp Bol 53: 2185-2191.

41. Pandey VP, Dwivedi UN (2015) A ripening associated peroxidase from papaya having a role in defense and lignification: Heterologous expression and in-silico and in-vitro experimental validation. Gene 555: 438-447.

42. Ostergaard L, Teilum K, Mirza O, Mattsson O, Petersen M, et al. (2000) Arabidopsis ATP A2 peroxidase. Expression and high-resolution structure of a plant peroxidase with implications for lignification. Plant Mol Biol 44: 231-243.

43. Quiroga M, Guerrero C, Botella MA, Barcelo A, Amaya I, et al. (2000) A tomato peroxidase involved in the synthesis of lignin and suberin. Plant Physiol 122 $1119-1128$

44. Lagrimini LM, Joly RJ, Dunlap JR, Liu TTY (1997) The consequence of peroxidase overexpression in transgenic plants on root growth and development. Plant Mol Biol 33: 887-895.

45. Espelie KE, Franceschi VR, Kolattukudy PE (1986) Immunocytochemica localization and time course of appearance of an anionic peroxidase associated with suberization in wound-healing potato tuber tissue. Plant Physiol 81: 487-492.

46. Vance CP, Kirk TK, Sherwood RT (1980) Lignification as a mechanism of disease resistance. Annual Rev Phytopathol 18: 259-288.

47. Fry SC (1986) Cross-linking of matrix polymers in the growing cells of angiospems. Ann Rev Plant Physiol 37: 165-186.

48. Bolwell GP, Bindschedler LV, Blee KA, Butt VS, Davies DR, et al. (2002) The apoplastic oxidative burst in response to biotic stress in plants: a threecomponent system. J Exp Bot 53: 1367-1376. 
Citation: Pandey VP, Awasthi M, Singh S, Tiwari S, Dwivedi UN (2017) A Comprehensive Review on Function and Application of Plant Peroxidases. Biochem Anal Biochem 6: 308. doi: 10.4172/2161-1009.1000308

49. Bolwell GP, Davies DR, Gerrish C, Auh CK, Murphy TM (1998) Comparative biochemistry of the oxidative burst produced by rose and French bean cells reveals two distinct mechanisms. Plant Physiol 116: 1379-1385.

50. Kawano T, Muto S (2000) Mechanism of peroxidase actions for salicylic acidinduced generation of active oxygen species and an increase in cytosolic calcium in tobacco suspension culture. J Exp Bot 51: 685-693.

51. Kristensen BK, Bloch H, Rasmussen SK (1999) Barley coleoptile peroxidases. Purification, molecular cloning and induction by pathogens. Plant physiol 20 501-512.

52. Thordal-Christensen H, Brandt J, Ho CB, Rasmussen, Soren K, et al. (1992) cDNA cloning and characterization of two barley peroxidase transcripts induced differentially by the powdery mildew fungus Erysiphe graminis. Physiol Mol Plant Pathol 40: 395-409.

53. Harrison SJ, Curtis MD, Mclntyre CL, Maclean DJ, Manners JM (1995). Differential expression of peroxidase isogenes during the early stages of infection of the tropical forage legume Stylosanthes humilis by Colletotrichum gloeosporioides. Mol Plant-Microbe Interact 8: 398-406.

54. Reimers PJ, Guo A, Leach JE (1992) Increased activity of a cationic peroxidase associated with an incompatible interaction between Xanthomonas oryzae $p v$ oryzae and rice (Oryza sativa). Plant Physiol 99: 1044-1050.

55. Rasmussen JB, Smith JA, Williams S, Burkhart W, Ward E, et al. (1995) cDNA cloning and systemic expression of acidic peroxidases associated with systemic acquired resistance to disease in cucumber. Physiol Mol Plan Pathol 46: 389-400.

56. Van Loon LC, Van Kammen A (1970) Polyacrylamide disc electrophoresis of the soluble leaf proteins from Nicotiana tabacum var. 'Samsun' and 'Samsun NN': II. Changes in protein constitution after infection with tobacco mosaic virus. Virol 40: 199-211.

57. Lagrimini LM, Rothstein S (1987) Tissue specificity of tobacco peroxidase isozymes and their induction by wounding and tobacco mosaic virus infection. Plant Physiol 84: 438-442.

58. Hiraga S, Ito H, Yamakawa H, Ohtsubo N, Seo S, et al. (2000a) An HR-induced tobacco peroxidase gene is responsive to spermine, but not to salicylate, methyl jasmonate, and ethephon. Mol. Plant Microbe Interact 13: 210-216.

59. Vera P, Tornero P, Conejero V (1993) Cloning and expression analysis of a viroid-induced peroxidase from tomato plants. Mol Plant Microbe Interact 6 790-794

60. Lovrekovich L, Lovrekovich H, Stahmann MA (1968) Tobacco mosaic virusinduced resistance to Pseudomonas tabaci in tobacco. Phytopathol 58 1034-1035.

61. Simons TJ, Ross AF (1970) Enhanced peroxidase activity associated with induction of resistance to tobacco masaic virus in hypersensitive tobacco. Phytopathol 60: 383-384.

62. Roberts E, Kutchan T, Kolattukudy PE (1988) Cloning and sequencing of cDNA for a highly anionic peroxidase from potato and the induction of its mRNA in suberizing potato tubers and tomato fruits. Plant Mol Biol 11: 15-26.

63. Svalheim O, Robertsen B (1990) Induction of peroxidases in cucumber hypocotyls by wounding and fungal infection. Physiologia Plant 78: 261-267.

64. Ishige F, Mori H, Yamazaki K, Imaseki H (1993) Identification of a basic glycoprotein induced by ethylene in primary leaves of azuki bean as a cationic peroxidase. Plant Physiol 101: 193-199.

65. Hiraga S, Yamamoto K, Ito H, Sasaki K, Matsui H, et al. (2000b) Diverse expression profiles of 21 rice peroxidase genes. FEBS Lett 471: 245-250.

66. Kawaoka A, Kawamoto T, Ohta H, Sekine M, Takano M, et al. (1994) Woundinduced expression of horseradish peroxidase. Plant Cell Rep 13: 149-154.

67. Kanazawa Y, Shichi H, Uritani I (1965) Biosynthesis of peroxidases in sliced or black rot-infected sweet potato roots. Agric Biol Chem 29: 840-847.

68. Mittler R (2002) Oxidative stress, antioxidants and stress tolerance. Trends Plant Sci 7: 405-410.

69. Asada K (1999) The water-water cycle in chloroplast: Scavenging of active oxygens and dissipation of excess photons. Annu Rev Plant Physiol Plant Mol Biol 50: 601- 639 .

70. Pelligrineschi A, Kis M, Dix I, Kavanagh TA, Dix PJ (1995) Expression of horseradish peroxidase in transgenic tobacco. Biochem Soc Trans 23: 247-250.
71. Blokhina O, Virolainen E, Fagerstedt KV (2003) Antioxidants, oxidative damage and oxygen deprivation stress: a review. Ann Bot 91: 179-194.

72. Normanly J (1997) Auxin metabolism. Physiol Plant 100: 431-442.

73. Jansen MA, Van den Noort RE, Tan MY, Prinsen E, Lagrimini LM, et al. (2001) Phenol oxidizing peroxidases contribute to the protection of plants from ultraviolet radiation stress. Plant Physiol 126: 1012-1023.

74. Schopfer $P$ (2001) Hydroxyl radical-induced cell-wall loosening in vitro and in vivo: implications for the control of elongation growth. Plant J 28: 679-688.

75. Hendricks SB, Taylorson RB (1974) Promotion of seed germination by nitrate, nitrite, hydroxylamine, and ammonium salts. Plant Physiol 54: 304-309.

76. Fridovich I (1976) Oxygen radicals, hydrogen peroxide and oxygen toxicity. In: Free radicals in biology. Pryor WA (Edn) Academic Press, New York. p 239-277.

77. Gaspar T, Penel C, Thorpe T, Greppin H (1982) Peroxidases 1970-1980. A survey of their biochemical and physiological roles in higher plants. Universite de Geneve, Geneve, 21-122.

78. Dendsay JPS, Sachar RC (1982) Hormonal control of peroxidase activity and its relationship with growth in mung bean seedlings. Plant Sci Lett 26: 251-256.

79. Sakai JS, Imaseki H (1971) Ethylene biosynthesis: Methionine as an in-vivo precursor of ethylene in auxin-treated mungbean hypocotyl segments. Planta 105: 165-173.

80. Fowler J, Morgan PW (1972) The relationship of the peroxidative indole acetic acid oxidase system to in vivo ethylene synthesis in cotton. Plant Physiol 59: 555-559.

81. Chaubey A, Malhotra BD (2002) Mediated biosensors. Biosens Bioelectron 17 441-456.

82. Lin SC (1979) Studies on fruit ripening. 1. Comparisons of ripening parameters peroxidase activity, and peroxidase zymograme of normal and in mutan tomatoes. J Agr Res China 28: 109-116.

83. Khan AA, Robinson DS (1993) Purification of anionic peroxidase isoenzyme from mango (Mangifera indica $L$. var. Chaunsa). Food Chem 46: 61-64.

84. Gorin N, Heidema FT (1976) Peroxidase activity in golden delicious apples as a possible parameter of ripening and senescence. J Agric Food Chem 24 200-201.

85. Haard NF (1973) Upsurge of particulate peroxidase in ripening banana fruit Phytochem 12: 555-560.

86. Kokkinakis DM, Brooks JL (1979) Tomato peroxidase: purification, characterization and catalytic properties. Plant Physiol 63: 93-99.

87. Civello PM, Martinez GA, Chaves AR, Cristina M (1995) Peroxidase from strawberry fruit (Fragaria ananassa Duch.): Partial purification and determination of some properties. J Agric Food Chem 43: 2596-2601.

88. Estrada B, Bernal MA, Diaz J, Pomar F, Merino F (2000) Fruit development in Capsicum annuum: Changes in capsaicin, lignin, free phenolics, and peroxidase patterns. J Agric Food Chem 48: 6234-6239.

89. Pandey VP, Singh S, Singh R, Dwivedi UN (2012) Purification and characterization of peroxidase from papaya (Carica papaya) fruit. Appl Biochem Biotechnol 167: 367-376.

90. Larkindale J, Huag B (2004) Thermotolerance and antioxidant systems in Agrosfis stolonifira: Involvement of salicylic acid, abscisic acid, calciurn hydrogen peroxide and ethylenc. J Plant Physiol 161: 405-413.

91. Edreva, A, Yordanov I, Karkjieva R, Georgieva ID, Gesheva E (1998) Involvement of peroxidases in heat shock responses of bean plants. Plant peroxidase newsletter 11: 27-34.

92. Neuinam P (1997) Salinity resistance and plant growth revisited. Plant Cell Environ 20: 1193-1198

93. Mums R (2002) Comparative physiology of salt and water stress. Plant Cell Environ 25: 239-250.

94. Amaya I, Botella MA, De La Calle M, Medina MI, Heredia A, et al. (1999) Improved gemination under osmotic stress of tobacco plants over expressing a cell wall peroxidase. FEBS Lett 457: 80-84.

95. Pujari DS, Chanda SV (2002) Effect of salinity stress on growth, peroxidase and IAA oxidase activities in vigna seedlings. Acta Physiologia Plantarum 24 435-439. 
Citation: Pandey VP, Awasthi M, Singh S, Tiwari S, Dwivedi UN (2017) A Comprehensive Review on Function and Application of Plant Peroxidases. Biochem Anal Biochem 6: 308. doi: 10.4172/2161-1009.1000308

96. Fontes RLF, Cox FR. (1995) Effects of sulphur supply on soybean plants exposed to zinc toxicity. J Plant Nut 18: 1893-1906.

97. Prasad KVSK, Paradha SP, Sharmila P (1998) Concerted action of antioxidant enzymes and curtailed growth under zinc toxicity in Brassica juncea. Environ Exp Bot 42: 1-10.

98. Assche FV, Clijsters H (1990) Effects of metal on enzyme activity in plants. Plant Cell Environ 13: 195-206.

99. Fang WC, Kao CH (2000) Enhanced peroxidase activity in rice leaves in response to excess iron, copper and zinc. Plant Sci 158: 71-76.

100. Abercrombie J, Halfhill M, Ranjan P, Rao MR, Saxton AM, et al. (2008) Transcriptional responses of Arabidopsis thaliana plants to As (V) stress. BMC Plant Biol 8: 87

101. Jordan BR (2002) Molecular responses of plant cells to UV-B radiation. UVradiation and its eflects workshop. Christ Church, New Zealand.

102. Jansen MAK, Elfstratid M, Heggie L, Sitbon F, Dix PJ, et al. (2004) Overexpression of phenol-oxidising peroxidases alters the UV-susceptibility of transgenic Nicotiana tabaccum. New Phytologist 163: 585-594.

103. Soda I, Hasegawa T, Suzuki T, Ogura N (1991) Purification and Some Properties of Peroxidase from Kiwi fruit. Agric Biol Chem 55: 1677-1678.

104. Kvaratskhelia M, Winkel C, Thorneley RN (1997) Purification and characterization of a novel class III peroxidase isoenzyme from tea leaves. Plant Physiol 114: 1237-1245.

105. Sakharov IY (2001) Long-term chemi-luminescent signal is produced in the course of luminol peroxidation catalyzed by peroxidase isolated from leaves of african oil palm tree. Biochem (Mosc.) 66: 515-519.

106. Neves VA (2002) Ionically bound peroxidase from peach fruit. Braz Arch Bio Technol 45: 7-16

107. Thongsook T, Barrett DM (2005) Heat inactivation and reactivation of broccol peroxidase. J Agric Food Chem 53: 3215-3222.

108. Caramyshev AV, Firsova YN, Slastya EA, Tagaev AA, Potapenko NV, et al. (2006) Purification and characterization of windmill palm tree (Trachycarpus fortunei) peroxidase. J Agric Food chem 54: 9888-9894.

109. Vernwal SK, Yadav RS, Yadav KD (2006) Purification of a peroxidase from Solanum melongena fruit juice. Ind J Biochem Biophy 43: 239-243.

110. Suzuki T, Honda Y, Mukasa Y, Kim SJ (2006) Characterization of peroxidase in buckwheat seed. Phytochem 67: 219-224.

111. Mohamed SA, El-Badry MO, Drees EA, Fahmy AS (2008) Properties of a cationic peroxidase from Citrus jambhiri cv. Adalia. Appl Biochem Biotechnol 150: $127-37$.

112. Kouakou TH, Dué EA, Kouadio NE, Niamke S, Kouadio YJ, et al. (2009) Purification and characterization of cell suspensions peroxidase from cotton (Gossypium hirsutum L.). Appl Biochem Biotechnol 157: 575-592.

113. Singh J, Dubey A, Diwakar SK, Rawat SK, Batra N, et al. (2010) Biochemical characterization of peroxidases from the fruits of Mallus pumilus. Int Res $\mathrm{J}$ Biotechnol 1: 50-58

114. Mohamed SA, Azza MA, Mohamed BH, Mohamed OE, Afaf SF (2011) Ficus sycomorus latex: A thermostable peroxidase, Afr J Biotechnol 10: 1753217543.

115. Pandey VP, Dwivedi UN (2011) Purification and characterization of peroxidase from Leucaena leucocephala, a tree legume. J Mol Catal B Enzym 68: 168-173.

116. Yves MEL, Mbassi MSEB, Wilfred M, John PM (2011) Heat stable peroxidases from Vigna species (V). Afr J Biotechnol 10: 3168-3175.

117. Hu Y, Wu J, Luo P, Mo Y (2012) Purification and partial characterization of peroxidase from lettuce stems. Afr J Biotechnol 11: 2752-2756.

118. Fortea MI, Pellicer J, Serrano-Martínez AA, Lopez-Miranda S, Lucas-Abellan C, et al. (2012) Red Cabbage (Brassica oleracea) as a New Source of HighThermostable Peroxidase. J Agric Food Chem 60: 10641-10648.

119. Nadaroglu H, Celebi N, Demir N, Demir $Y$ (2013) Purification and characterisation of a plant peroxidase from rocket (Eruca vesicaria sbsp. Sativa) (Mill.) (syn. E. sativa) and effects of some chemicals on peroxidase activity in vitro. Afr J Agric Res 8: 2520-2528.
120. Mall R, Naik G, Mina U, Mishra SK (2013) Purification and characterization of a thermostable soluble peroxidase from Citrus medica leaf. Prep Biochem Biotechnol 43.

121. Sergeyeva TA, Lavrik N, Rachkov AE (1999) Hydrogen peroxide - sensitive enzyme sensor based on phthalocyanine thin film. Anal Chim Acta 391 289-297.

122. Adams JB (1997) Regeneration and the kinetics of peroxidase inactivation. Food Chem 60: 201-206.

123. Jia J, Wang B, Cheng G, Dong S (2002)A method to construct a third generation horseradish peroxidase biosensor: self-assembling gold nanoparticles to three dimensional sol-gel network. Anal Chem 74: 2217-2223.

124. Zhang $\mathrm{Y}, \mathrm{He} \mathrm{P}, \mathrm{Hu} \mathrm{N}$ (2004) Horseradish peroxidase immobilized in $\mathrm{TiO}$ nanoparticle films on pyrolytic graphite electrodes: direct electrochemistry and bioelectrocatalysis. Electrochim Acta 49: 1981-1988.

125. Zhang $Y$, Zhang $Y$, Wang H, Yan B, Shen G, et al. (2009) An enzyme immobilization platform for biosensor designs of direct electrochemistry using flower-like $\mathrm{ZnO}$ crystals and nano-sized gold particles. J Electroanal Chem 627: 9-14.

126. Lindgren A, Ruzgas T, Gorton L, Csoregi E, Bautista AG, et al. (2000) Biosensors based on novel peroxidases with improved properties in direct and mediated electron transfer. Biosens Bioelectron 15: 491-497.

127. Liu H, Ying T, Sun K, Li H, Qi D (1997) Reagentless amperometric biosensors highly sensitive to hydrogen peroxide, glucose and lactose based on N-methyl phenazine methosulfate incorporated in a Nafion film as an electron transfer mediator between horseradish peroxidase and an electrode. Anal Chim Acta 344: 187-199.

128. Martin SP, Lynch JM, Reddy SM (2002) Optimisation of the enzyme-based determination of hydrogen peroxide using the quartz crystal microbalance. Biosens Bioelectron 17: 735-739.

129. Ghindilis AL, Atanasov P, Wilkins E (1996) Potentiometric immunoelectrode for fast assay based on direct electron transfer catalyzed by peroxidase. Sensor Actuators B Chem 34: 528-532.

130. Wang XQ, Li LS, Vander Meer BW, Jin J, Tang D, et al. (2001) Comparison of photovoltaic behaviors for horseradish peroxidase and its mimicry by surface photo voltage spectroscopy. Biochim Biophys Acta 1544: 333-340.

131. Choi J, Lim IH, Kim HH, Min J, Lee WH (2001) Optical peroxide biosensor using the electrically controlled-release technique. Biosens Bioelect 16: 141-146.

132. Rubtsova MY, Kovba GV, Egorov AM (1998) Chemiluminescent biosensors based on porous supports with immobilized peroxidase. Biosens Bioelectron 13: $75-85$.

133. Pisoschi AM (2016) Potentiometric biosensors: Concept and analytical applications-An Editorial. Biochem Anal Biochem 5: e164.

134. Pastor I, Esquembre R, Micol V, Mallavia R, Mateo CR (2004) A ready-to-use fluorimetric biosensor for superoxide radical using superoxide dismutase and peroxidase immobilized in sol-gel glasses. Anal Biochem 334: 335-343.

135. Casero E, Darder M, Pariente F, Lorenzo E (2000) Peroxidase enzyme electrodes as nitric oxide biosensors. Anal Chim Acta 403: 1-9.

136. Mao L, Yamamoto K (2000) Amperometric biosensor for glutathione based on Osmium-Polyvinylpyridine gel polymer and glutathione sulfhydryl oxidase. Electroanalysis 12: 577-582

137. Akyilmaz E, Sezginturk MK, Dinckaya E (2003) A biosensor based on urate oxidase peroxidase coupled enzyme system for uric acid determination in urine. Talanta 61: 73-79.

138. DM, Ferrer ML, Mateo CR (2003) A reagent less fluorescent sol-gel biosensor for uric acid detection in biological fluids. Anal Biochem 322: 238-242.

139. Imabayashi S, Kong Y, Watanabe M (2001) Amperometric biosensor for polyphenol based on horseradish peroxidase immobilized on gold electrodes. Electroanalysis 13: 408-412.

140. Kong YT, Imabayashi S, Kano K, Ikeda T, Kakiuchi T (2001) Peroxidasebased amperometric sensor for the determination of total phenols using twostage peroxidase reactions. Am J Enol Vitic 52: 381-385.

141. Mello LD, Alves AA, Macedo DV, Kubota LT (2005) Peroxidase-based biosensor as a tool for a fast evaluation of antioxidant capacity of tea. Food Chem 92: 515-519. 
Citation: Pandey VP, Awasthi M, Singh S, Tiwari S, Dwivedi UN (2017) A Comprehensive Review on Function and Application of Plant Peroxidases. Biochem Anal Biochem 6: 308. doi: 10.4172/2161-1009.1000308

142. Castillo J, Ferapontova E, Hushpulian D, Tasca F, Tishkov V et al. (2006) Direct electrochemistry and biolelectrocatalysis of $\mathrm{H}_{2} \mathrm{O}_{2}$ reduction of recombinant tobacco peroxidase on graphite. Effect of peroxidase single-point mutation on $\mathrm{Ca}^{2+}$-modulated catalytic activity. J Electroanal Chem 588: 112-121.

143. Vreeke MS, Yong KT, Heller A (1995) A thermostable hydrogen peroxide sensor based on "wiring" of soybean peroxidase. Anal Chem 67: 4247-4249.

144. Belcarz A, Ginalska G, Kowalewska B, Kulesza P (2008) Spring cabbage peroxidases-Potential tool in biocatalysis and bioelectrocatalysis. Phytochem 69: $627-636$

145. Ferapontova EE, Castello J, Gorton L (2006) Bioelectrocatalytic properties of lignin peroxidase from Phanerochaete chrysosporium in reactions with phenols, catechols and lignin model compounds. Biochim Biophys Acta 1760: 1343-1354.

146. Veitch NC (2004) Horseradish peroxidase: A modern view of a classic enzyme. Phytochem 65: 249-259.

147. Krell HW (1991) Peroxidase: An important enzyme for diagnostic test kits. In: Biochemical, molecular and physiological aspects of plant peroxidases. Lobarzewsky J, Greppin H, Penel C, Gasparm T (eds) University M Curie Lublind Poland and University of Geneva, Geneva Switzerland, 469-478.

148. Agostini E, Hernandez-Ruiz J, Arnao MB, Milrad SR, Tigier HA, et al. (2002) A peroxidase isoenzyme secreted by turnip (Brassica napus) hairy-roo cultures: inactivation by hydrogen peroxide and application in diagnostic kits. Biotechnol Appl Biochem 35: 1-7.

149. Ragland BD, Konrad RJ, Chaffin C, Robinson CA, Hardy RW (2000) Evaluation of a homogeneous direct LDL-cholesterol assay in diabetic patients: effect of glycemic control. Clin Chem 46: 1848-1851.

150. Malik V, Pundir C (2002) Determination of total cholesterol in serum by cholesterol esterase and cholesterol oxidase immobilized and coimmobilized on to arylamine glass. Biotechnol Appl Biochem 35: 191-197.

151. Chiou CC, Chang PY, Chan EC, Wu TL, Tsao KC, et al. (2003) Urinary 8-dydroxyguanosine and its analogs as DNA marker of oxidative stress: development of an ELISA and measurement in both bladder and prostate cancers. Clin Chim Acta 334: 87-94.

152. Heller A, Vreeke MS (1997) Soybean peroxidase electrochemical sensor USA Patent US 5665222.

153. Sharma SK, Sehgal N, Kumar A (2002) A quick and simple biostrip technique for detection of lactose. Biotechnol Lett 24: 1737-1739.

154. Greco O, Folkes LK, Wardman P, Tozer GM, Dachs GU (2000) Development of a novel enzyme/prodrug combination for gene therapy of cancer: horseradish peroxidase/indole-3-acetic acid. Cancer Gene Ther 7: 1414-1420.

155. Folkes LK, Greco O, Dachs GU, Stratford MRL, Wardman P (2002) 5-fluoroindole-3-acetic acid: a prodrug activated by a peroxidase with potential for use in targeted cancer therapy. Biochem Pharmacol 63: 265-272.

156. Melton RG, Sherwood RF (1969) Antibody-enzyme conjugates for cance therapy. J Natl Cancer Inst 88: 153-165.

157. Ahmed SR, Kim J, Suzuki T, Lee J, Park EY (2016) Detection of influenza virus using peroxidase-mimic of gold nanoparticles. Biotechnol Bioeng 113: 2298-2303.

158. An SY, Min SK, Cha IH, Choi YL, Cho YS, et al. (2002) Decolorization of triphenylmethane and azo dyes by Citrobacter sp. Biotechnol Lett 24: 10371040.

159. Chivukula M, Spadaro JT, Renganathan V (1995) Lignin peroxidase-catalyzed oxidation of sulfonated azo dyes generates novel sulfophenyl hydroperoxides. Biochem 34: 7765-7772.

160. Tatsumi K, Ichikawa H (1996) Removal of chlorophenols from wastewater by immobilized horseradish peroxidase. Biotechnol Bioeng 51: 126-130.

161. Bhunia A, Durani S, Wangikar PP (2001) Horseradish peroxidase catalyzed degradation of industrially important dyes. Biotechnol Bioeng 72: 562-567.

162. Hatakka A (1994) Lignin-modifying enzymes from selected white-rot fungi: production and roles in lignin degradation. FEMS Microbiol Rev 13: 125-135.

163. Kim SJ, Shoda M (1999) Purification and characterization of a nove peroxidase from Geotrichum candidum involved in decolorization dyes. Appl Environ Microbiol 65: 1029-1035
164. Pandey VP, Dwivedi UN (2015) A ripening associated peroxidase from papaya having a role in defense and lignification: Heterologous expression and insilico and in-vitro experimental validation. Gene 555: 438-447.

165. Maciel HPF, Gouvea CMCP, Pastore GM (2006) Obtention of a new source of peroxidase from Copaifera langsdorffii Desf. with high activity. Cienciae Tecnologia de Alimentos 26: 735-739.

166. Maciel HPFG, Gouvea CMCP, Pastore GM (2007) Extraction and partial characterization of peroxidase from Copaifera langsdorffii Desf. leaves. Cienciae Tecnologia de Alimentos 27: 221-225.

167. Husain Q (2006) Potential applications of the oxidoreductive enzymes in the decolorization and detoxification of textile and other synthetic dyes from polluted water: a review. Crit Rev Biotechnol 60: 201-221.

168. Baldrian P, Snajdr J (2006) Production of ligninolytic enzymes by litterdecomposing fungi and their ability to decolorize synthetic dyes. Enzyme Microb Technol 395: 1023-1029.

169. Ferreira-Leitao VS, deCarvalho MEA, Bon EPS (2007) Lignin peroxidase efficiency for methylene blue decolouration: comparison to reported methods. Dyes and Pigments 74: 230-236.

170. Duarte-Vazquez MA, Ortega-Tovar MA, Garcia-Almendarez BE, Regalado C (2003) Removal of aqueous phenolic compounds from a model system by oxidative polymerization with turnip (Brassica napus L. var. purple top white globe) peroxidase. J Chem Technol Biotechnol 78: 42-47.

171. Souza SMAGU, Forgiarini E, de Souza AAU (2007) Toxicity of textile dyes and their degradation by the enzyme horseradish peroxidase (HRP). J Hazard Mater 147: 1073-1078.

172. Akhtar S, Khan AA, Husain Q (2005) Partially purified bitter gourd (Momordica charantia) peroxidase catalyzed decolorization of textile and other industrially important dyes. Bioresour Technol 96: 1804-1811.

173. Sakuyama H, Endo Y, Fujimoto K Hatano Y (2003) Oxidative degradation of alkylphenols by horseradish peroxidase. J Biosci Bioengin 96: 227-231.

174. Silva MC, Torres JA, Correa, AD, Junqueira AMB, Amorim MTP, et al. (2012) Obtention of plant peroxidase and its potential for the decolorization of the reactive dye Remazol Turquoise G 133\%. Water Sci Technol 65: 669-675.

175. Barreto WJ, Bernardino ND, Afonso R, Doi SMO (2011) Biodegradation of a mixture of textile dyes using the fungus Ganodermasp: a kinetic study. Quimica Nova 34:568-572.

176. Husain Q (2010) Peroxidase mediated decolorization and remediation of wastewater containing industrial dyes: a review. Rev Environ Sci Biotechno 9: $117-140$

177. Shaffiqu T, Roy J, Nair RA, Abraham TE (2002) Degradation of textile dye mediated by plant peroxidases. Appl Biochem Biotechnol 102-103: 315-326.

178. Nicell JA, Al-Kassim L, Bewtra JK, Taylor KE (1993) Wastewater treatment by enzyme catalyzed polymerization and precipitation. Biodeterior Abst 7: 1-8.

179. Karam J, Nicell JA (1997) Potential application of enzymes in waste treatment. J Chem Technol Biotechnol 69: 141-153.

180. Wagner M, Nicell JA (2001) Peroxidase-catalyzed removal of phenols from a petroleum refinery wastewater. Water Sci Technol 43: 253-260.

181. Wagner M, Nicell JA (2002) Detoxification of phenolic solutions with horseradish peroxidase and hydrogen peroxide. Water Res 36: 4041-4052.

182. Klibanov AM, Tu TM, Scott KP (1983) Peroxidase-catalyzed oxidation of phenols from coal-conversion waste waters. Science 221: 259-261.

183. Bewtra JK, Biswas N, Henderson WD, Nicell JA (1995) Recent advances in treatment of selected hazardous wastes. Water Qual Res J Can 30: 115-125.

184. Caza N, Bewtra JK, Biswas N, Taylor KE (1999) Removal of phenolic compounds from synthetic wastewater using soybean peroxidase. Water Res 33: $3012-3018$

185. Kinsley C, Nicell JA(2000) Treatment of aqueous phenol with soybean peroxidase in the presence of polyethylene glycol. Bioresor Technol 73: 139-146.

186. Kennedy K, Alemany K, Warith M (2002) Optimization of soybean peroxidase treatment of 2,4-dichlorophenol. Water SA 28: 149-158.

187. Hatakka A, Hakala T, Lundell T, Horichter M, Maijala P (2002) Manganese peroxidase-the key enzyme in lignin biodegradation and biopulping by white-rot fungi? 223 ${ }^{\text {rd }}$ ACS National Meeting (CELL-028) Orlando, FL, ACS, Washington. 
Citation: Pandey VP, Awasthi M, Singh S, Tiwari S, Dwivedi UN (2017) A Comprehensive Review on Function and Application of Plant Peroxidases. Biochem Anal Biochem 6: 308. doi: 10.4172/2161-1009.1000308

188. Hatakka A, Lundell T, Hofrichter M, Maijala P (2003) Manganese peroxidase and its role in the degradation of wood lignin. In: Applications of enzymes to lignocellulosics. Mansfield SD, Saddler JN (Edn) ACS Symposium Series 855, Washington, 230-243.

189. Aehle W (2007) Enzymes in industry: Production and Applications. Wiley, New York. ISBN-13: 978-3527316892.

190. Kawamura O, Sato S, Kajii H, Nagayama S, Ohtani K, et al. (1989) A sensitive enzyme-linked immunosorbent assay of ochratoxin-A based on monoclonal antibodies. Toxicon 27: 887-897.

191. Clarke JR, Marquardt RR, Oosterveld A, Frohlich AA, Madrid FJ, et al. (1993) Development of a quantitative and sensitive enzyme linked immunosorbent assay for ochratoxin-A using antibodies from the yolk of the laying hen. J Agric Food Chem 41: 1784-1789.

192. Ramakrishna N, Lacey J, Candish AAG, Smith JE, Goodbrand IA (1990) Monoclonal antibody-based enzyme linked immune-sorbent assay of aflatoxin B1, T-2 toxin and ochratoxin-A in barley. J Assoc Anal Chem 73: 71-77.

193. Kawatsu K, Hamano Y, Sugiyama A, Hashizume K, Noguchi T (2002) Development and application of an enzyme immunoassay based on a monoclonal antibody against gonyautoxin components of paralytic shellfish poisoning toxins. J Food Protect 65: 1304-1308.

194. De Saeger S, Van PC (1996) Dipstick enzyme immunoassay to detect Fusarium T2 toxin in wheat. Appl Environ Microbiol 62: 1880-1884.

195. Young PR (1989) An improved method for the detection of peroxidaseconjugated antibodies on immunoblots. J Virol Meth 24: 227-236.

196. Zhuang H, Cui Y, Zhu W, Zhu Y, Xu G (2001) Development of a disgnostic kit of enzyme linked immunoassay for detecting serum anti-hepatitis $E$ virus IgG. Zhongua Yufang Yixue Zazhi 35: 315-317.

197. Vega-Warner AV, Gandhi H, Smith DM, Ustonol Z (2000) Polyclonal-antibodybased ELISA to detect milk alkaline phosphatase. J Agric Food Chem 48 2087-2091.

198. Tiirola T, Jaakkola A, Bloigu A, Paldanius M, Sinisalo J, et al. (2006) Novel enzyme immunoassay utilizing lipopolysaccharide-binding protein as a capture molecule for the measurement of chlamydial lipopolysaccharide in serum. Diagn Microbiol Infect Dis 54: 7-12.

199. De Luis R, Lavilla M, Sanchez L, Calvo M, Perez MD (2009) Development and evaluation of two ELISA formats for the detection of $\beta$-lactoglobulin in model processed and commercial foods. Food Control 20: 643-647.

200. Renz M, Kurz C (1984) A colorimetric method for DNA hybridization. Nucleic Acids Res 12: 3435-3444.

201. Vianello F, Zennaro L, Di Paolo ML, Rigo A, Malacarne C, et al. (2000) Preparation, morphological characterization, and activity of thin films of horseradish peroxidase. Biotechnol Bioeng 68: 488-495.

202. Van Gijlswijk RP, Talman EG, Peekel I, Bloem J, van Velzen MA, et al (2002) Use of horseradish peroxidase and fluorescein-modified cisplatin derivatives for simultaneous labeling of nucleic acids and proteins. Clin Chem 48: 1352-1359.

203. Yakovleva J, Davidsson R, Lobanova A, Bengtsson M, Eremin S, et al. (2002) Microfluidic enzyme immunoassay using silicon microchip with immobilized antibodies and chemiluminescence detection. Anal Chem 74: 2994-3004

204. Moody MD, Van Arsdell SW, Murphy KP, Orencole SF, Burns C (2001) Arraybased ELISAs for high-throughput analysis of human cytokines. Biotechniques 31: 192-194.

205. Curey TE, Salazar MA, Oliveira P, Javier J, Dennis PJ, et al. (2002) Enzymebased sensor arrays for rapid characterization of complex disaccharide solutions. Anal Biochem 303: 42-48.

206. Huttermann A, Mai C, Kharazipour A (2001) Modification of lignin for the production of new compounded materials. Appl Microbiol Biotechnol 55 : 387-384.

207. Gross RA, Kumar A, Kalra B (2001) Polymer synthesis by in vitro enzyme catalysis. Chem Rev 101: 2097-2124.

208. Van Deurzen MPJ, Rantwijk FV, Sheldon RA (1997) Selective oxidations catalyzed by peroxidases. Tetrahedr 53: 13183-13220

209. Colonna S, Gaggero N, Richelmi C, Pasta P (1999) Recent biotechnological developments in the use of peroxidases. Trends Biotechnol 17: 163-168.
210. Eker B, Zagorevski D, Zhu G, Linhardt RJ, Dordick JS (2009) Enzymatic polymerization of phenols in room-temperature ionic liquids. J Mol Catal $B$ Enzym 59: 177-184.

211. Blinkovsky AM, Dordick JS (1993) Peroxidase-catalyzed synthesis of ligninphenol copolymers. J Polym Sci A Polym Chem 31: 1839-1846.

212. Dordick JS (1992) Enzymatic and chemoenzymatic approaches to polymer synthesis. Trends Biotechnol 10: 287-293.

213. Liu J, Yuan W, Lo T (1999) Copolymerization of lignin with cresol catalyzed by peroxidase in reversed micellar systems. Elect J Biotechnol 2: 82-87.

214. Lora JH, Glasser WG (2002) Recent industrial applications of lignin: a sustainable alternative to nonrenewable materials. J Polym Environ 10: 39-48.

215. Kosbar LL, Gelorme JD, Japp RM Fotorny WT (2000) Introducing biobased materials into the electronics industry. $\mathrm{J}$ Ind Ecol 4: 93-105.

216. Sena-Martins G, Almeida-Vara E, Duarte JC (2008) Eco-friendly new products from enzymatically modified industrial lignins. Ind Crops Prod 27: 189-195.

217. Ikeda R, Sugihara J, Uyama H, Kobayashi S (1996) Enzymatic oxidative polymerization of 2,6-dimethylphenol. Macromolecules 29: 8702-8705

218. Kim YH, An ES, Song BK, Kim DS, Chelikani R (2003) Polymerization of cardanol using soybean peroxidase and its potential application as antibiofilm coating material. Biotechnol Lett 25: 1521-1524.

219. Kalra B, Gross RA (2000) Horseradish peroxidase mediated free radical polymerization of methyl ethacrylate. Biomacromol 1: 501-505.

220. Emery O, Lalot T, Brigodiot M, Marechal E (1997) Free-radical polymerization of acrylamide by horseradish peroxidase-mediated initiation. J Polym Sci A Polym Chem 35: 3331-3333.

221. Lalot T, Brigodiot M, Marechal E (1999) A kinetic approach to acrylamide radical polymerization by horseradish peroxidase-mediated initiation. Polym Int 48: 288-292.

222. Teixeira D, Lalot T, Brigodiot M, Marechal E (1999) $\beta$-Diketones as key compounds in free-radical polymerization by enzyme-mediated initiation. Macromol 32: 70-72.

223. Karla B, Gross RA (2002) HRP-mediated polymerization of acrylamide and sodium acrylate. Green Chem 4: 174-178.

224. Iwahara K, Hirata M, Honda Y, Watanabe T, Kuwahara M (2000) Free-radical polymerization of acrylamide by manganese peroxidase produced by the white-rot basidiomycete Bjerkandera adusta. Biotechnol Lett 22: 1351-1361.

225. Singh A, Ma D, Kaplan DL (2000) Enzyme-mediated free radical polymerization of styrene. Biomacromol 1: 592-596.

226. Cholli AL, Thiyagarajan M, Kumar J, Parmar VS (2005) Biocatalytic approaches for synthesis of conducting polyaniline nanoparticles. Pure Appl Chem 77: 339-344

227. Raitman OA, Katz E, Buckmann AF, Willner I (2002) Integration of polyaniline/ poly (acrylic acid) films and redox enzymes on electrode supports: an in situ electrochemical/surface plasmon resonance study of the bioelectrocatalyzed oxidation of glucose or lactate in the integrated bio-electrocatalytic systems. $J$ Am Chem Soc 124: 6487-6496.

228. Cao Y, Li S, Xue Z, Guo D (1986) Spectroscopic and electrical characterization of some aniline oligomers and polyaniline. Synth Met 16: 305-315

229. Chiang J, Mac Diarmid AG (1986) 'Polyaniline': protonic acid doping of the emeraldine form to the metallic regime. Synth Met 13: 193-205.

230. Samuelson LA, Anagnostopoulos A, Alva KS, Kumar J, Tripathy SK (1998) Biologically derived conducting and water soluble polyaniline. Macromol 31 : 4376-4378.

231. Rannou P, Gawlicka A, Berner D, Pron A, Nechtsschein M (1998) Spectroscopic, structural and transport properties of conducting polyaniline processed from fluorinated alcohols. Macromol 31: 1307-1315.

232. Lui W, Kumar J, Tripathy S, Senecal KJ, Samuelson L (1999) Enzymatically synthesized conducting polyaniline. J Am Chem Soc 121: 71-78.

233. Chottopadhyay K, Mazumdar S (2000) Structural and conformational stability of horseradish peroxidase: effect of temperature and pH. Biochem 9: 125-132.

234. Sakharov IY, Vorobiev AC, Castillo LJJ (2003) Synthesis of polyelectrolyte complexes of polyaniline and sulfonated polystyrene by palm tree peroxidase. Enzyme Microb Technol 33: 661-667. 
Citation: Pandey VP, Awasthi M, Singh S, Tiwari S, Dwivedi UN (2017) A Comprehensive Review on Function and Application of Plant Peroxidases. Biochem Anal Biochem 6: 308. doi: 10.4172/2161-1009.1000308

Page 16 of 16

235. Nagarajan R, Samuelson L, Tripathy S, Liu W, Kumar J, et al. (2003) Enzymatic polymerization of anilines or phenols around a template. US Pat No 6569651.

236. Nicell JA, Wright $H$ (1997) A model of peroxidase activity with inhibition by hydrogen peroxide. Enz Microbiol Technol 21: 302-310.

237. Wright H, Nicell JA (1999) Characterization of soybean peroxidase for treatment of aqueous phenols. Bioresour Technol 70: 69-79.

238. Sottomayor M, Lopez-Serrano M, Di Cosmog F, Ros Barcelo A (1998)
Purification and characterization of $\alpha-3^{\prime}, 4^{\prime}$-anhydrovinblastine synthase (peroxidase-like) from Catharanthus roseus (L.) G. Don. FEBS Lett 428: 299-303.

239. Sottomayor M, Di Cosmog F, Ros Barcelo A (1997) On the fate of catharanthine and vindoline during the peroxidase-mediated enzymatic synthesis of $\alpha-3$ ', 4'-anhydrovinblastine. Enzyme Microb Technol 21: 543-549.

240. Goodbody AE, Endo T, Vukovic J, Kutney JP, Choi LS, et al. (1988) Enzymic coupling of catharanthine and vindoline to form 3', 4'-anhydrovinblastine by horseradish peroxidase. Planta Med 54: 136-140. 